\title{
SCALAR AND VECTOR GAMES IN THE EVALUATION OF SOCIAL AND ENVIRONMENTAL DISCLOSURE AND THEIR RELATIONSHIP WITH MARKET VALUE
}

\author{
Adriana Kroenke $^{1 *}$, Victoriana Rubiales Caballero ${ }^{2}$, \\ Bianca $\mathrm{Cecon}^{3}$ and Nelson Hein ${ }^{1}$
}

Received November 7, 2017 / Accepted March 17, 2018

\begin{abstract}
This study evaluated the association of social, environmental and socio-environmental disclosure with the market value of Brazilian companies with high environmental impact based on the Game Theory. To perform the analysis, rankings were developed by using scalar and vector gaming techniques. After the construction of the rankings, the association between them was verified through Kendall's correlation analysis. The findings indicate a positive association of social, environmental and socio-environmental disclosure with the market value of Brazilian companies with high environmental impact. In addition, there was an increase in the degree of association during the investigated periods. This result suggests that the market is increasingly demanding regarding the disclosure of this information, which indicates that the disclosure of these information can bring competitive advantages in relation to the market value.
\end{abstract}

Keywords: socio-environmental disclosure, market value, game theory.

\section{INTRODUCTION}

Interest in socio-environmental issues has been growing significantly in recent years (Cintra, 2011). Sousa, Silva, Ribeiro \& Weffort (2014) emphasize that social and environmental disclosures have gained prominence due to the initiatives of national and international organizations concerned with social responsibility and due to the broad recognition of debates regarding sustainability. However, according to Bauer \& Naime (2012), the studies regarding this topic still remain scarce in the Brazilian scenario, which encourages the conduction of new researches to better understand the field and to fill this research gap.

\footnotetext{
*Corresponding author.

${ }^{1}$ Universidade Regional de Blumenau, Rua Antônio da Veiga, 140 - Itoupava Seca, 89030-903 Blumenau, SC, Brasil. Tel.: (47) 3321-0565 - E-mails: akroenke@ furb.br; hein@furb.br

${ }^{2}$ Universidad de Sevilla, Departamento de Economia Aplicada III, C/S. Fernando, 4, C.P. 41004 - Sevilla, España. E-mail: vrubiales@us.es

${ }^{3}$ Universidade Federal do Paraná, Centro Politécnico, 81531-980 Curitiba, PR, Brasil. E-mail: bcecon@ outlook.com
} 
In light of voluntary disclosure by organizations, Dye (2001) states that there is a Theory of Voluntary Disclosure. For the author, this theory has as its central premise that organizations will only disclose information that is favorable to them and will not disclose information that is unfavorable. Therefore, if companies do not disclose some information, the market will consequently interpret it as negative, because if it were positive, there would be no reason why companies would hide such information (Dye, 1985; Salotti \& Yamamot, 2005). Verrecchia (1983) also points out that users may even think that the information not shown is positive, but they will think at the same time that, because they have not been shown, they are not positive enough to compensate costs.

According to Santos, Araújo \& Leite Filho (2016) there have been advances, in developed capital markets, in the investigations of topics related to the research of voluntary disclosure which involve the relationship between voluntary disclosure and the market value of companies. However, Uyar \& Kiliç (2012) mention that this is not the reality which is evidenced in researches with companies of emerging capital markets, since such relationship is still an unexplored topic. In this sense, there is scope in this research gap regarding the association between voluntary disclosure and market value in emerging market companies. In addition, the relevance of investigating such association in the Brazilian context to the construction of scientific knowledge is emphasized, since Brazil is one of the emerging countries of the world (Murcia, 2009).

Thus, considering the current scenario in which external users of the organization are increasingly demanding transparency from companies in relation to the socio-environmental issues they face (Sobhani, Amran \& Zainuddin, 2009), the non-disclosure of this information may prejudice the image of the company. This occurs because if the organization omits certain information, the market can assume that the value of the same company is being overestimated, which can lead investors to sell their shares, and this consequently entails a lower market value for this company compared to its competitors who disclose information (Dye, 1985).

In this context, considering that voluntary disclosure tends to be associated with the companies' market value, according to the conclusion of Dye (1985) in relation to Voluntary Disclosure Theory, this research seeks to evaluate the association between the disclosure of social, environmental and socio-environmental information, which are voluntary in the national context, with the market value of the same companies, in order to verify empirical evidences related to such association.

In view of the research aspects presented in the literature and its previous results, this study seeks to answer the following research question: What is the association between socio-environmental disclosure with the market value of Brazilian companies with high environmental impact? In order to answer the aforementioned research problem, the main goal which this research aims to achieve is to assess the association of socio-environmental disclosure with the market value of Brazilian companies with a high environmental impact, through scalar and vector games, given the characteristics of the groups of indicators (social and environmental). 
The measurement of the social, environmental, and socio-environmental disclosures and market value make up the originality of the research and, similarly, its scientific contribution indeed. Non-triviality is achieved by the composition of the variables, sample and methods, as well as the volume and extent of the analysis. In short, these elements of the scientific tripod account for the impact and contribution to the area of operational research.

The uniqueness sought by this research arises from two contributions. The first one related to the measurement of the market value of the organizations, using as metric the stock price. This metric was verified only in international studies that analyzed the association between the socioenvironmental disclosure and the market value of companies. There are no records of national studies of this kind. The second one comes from the technique used in the process of company ranking according to the level of social, environmental and socio-environmental disclosure that, for the lack of a better view, was not found in previous surveys. The results of the ranking of the companies according to social, environmental and socio-environmental disclosure were obtained using tools related to Game Theory. Specifically, scalar games (unicriteria) in the formation of rankings of social and environmental disclosure and vector games (multicriteria) in the formation of rankings of socio-environmental disclosure.

The study is justified by the debate regarding the association of voluntary disclosure and the market value of companies. Currently there are two aspects, one argues that disclosure of voluntary information adds value to the company, since it increases the competitive advantage of the organization, taking the company to a higher market value than its competitors that do not disclose information. The other part argues that voluntary disclosure represents only an increase in costs to the organization and consequently results in a lower market value for the company, according to Olayinka \& Oluwamayowa (2014).

\section{INFORMATION DISCLOSURE}

The information disclosure can be interpreted as being the channel of information transmission of the company to the market (Murcia, 2009). According to Healy \& Palepu (2001) and Francis, Nanda \& Olsson (2008), the information disclosure is demanded by the market as a consequence of the informational asymmetry that occurs between internal users and external users of the company, since internal users usually have more information about the organization than external users.

According to Bushman \& Smith (2001), the higher the level of disclosure of the company, the better the expectations of investors, customers, suppliers, consumers, government and society in relation to the organization, which tends to value the company. In light of this competitive advantage, several companies that disclose information beyond what is done as a result of regulation appear in the global scenario. Such disclosure is called voluntary disclosure and, unlike the compulsory disclosure, it occurs on the part of the company even though there is no legal obligation (Yamamoto \& Salotti, 2006). 
According to Malacrida \& Yamamoto (2006), the highest level of voluntary disclosure by companies occurs due to the expectation of a positive repercussion of this information in the market, thus improving the financial situation of the company. Sousa, Silva, Ribeiro \& Weffort (2014) point out that, at present, the voluntary disclosure occurs due to the organizations' need to differentiate themselves from the others which are in the market, in such a way that the disclosure can provide decisions of the agents that maximize the value of the organization.

In the international context, the field of research that involves issues related to the disclosure of voluntary information of companies is relatively advanced (Healy \& Palepu, 2001). It is possible to verify several studies on this subject in countries such as: Balgadesh, France, Hong Kong, Japan, Malaysia, Mexico, the Czech Republic, Sweden and Switzerland (Murcia, 2009). The frequency of studies is incipient in capital markets in underdeveloped and emerging countries, as is the case in Brazil. Lanzana (2004) confirms that in the national context, this field of research still remains scarce.

Regarding the disclosure made voluntarily by organizations, the highlight in the national context is the disclosure of socio-environmental information. In Brazilian organizations, the disclosure of social and environmental information is considered voluntary, since there are no rules regulating the disclosure of such issues. However, it is worth highlighting the strong recommendations of the Brazilian Electricity Regulatory Agency - Agência Nacional de Energia Elétrica in Portuguese (ANEEL) - for companies that operate in the electricity sector to disclose certain socio-environmental information (Rover, 2013).

For Santos, Araújo \& Leite Filho (2016), the main justification for conducting research involving such an association is due to the issue of being directly related to the fact that the manager discloses information to stakeholders. According to Rover \& Santos (2014), investigating this issue contributes with the companies, as these can improve their issues regarding the disclosure of the findings of such association. In addition, if a higher market value were evidenced due to the disclosure of socio-environmental information, this fact could encourage companies to disclose such information (Souza, 2013), which would contribute to reducing the problem of informational asymmetry in companies. Therefore, it is important to investigate the relationship between socioenvironmental disclosure and its relevance to the capital market is important both for the academic scope and for the users of the information (Rover, 2013).

At the national level, research that investigated the association between socio-environmental disclosure and market value has so far used only the binary form to measure disclosure. Given this issue, the present research seeks to innovate using the linear measurement form, as conducted by Rover (2013) when investigating the relationship between the socio-environmental disclosure and the cost of equity of companies. This method of measurement is appropriate since it allows to verify not only the quantity, but the quality of the information evidenced, as mentioned by Cormier, Magnam \& Val Velthoven (2005). 


\section{METHOD AND RESEARCH PROCEDURES}

This section presents the method and procedures used in the study when achieving the proposed objectives and is divided into four subdivisions. Initially, there is a discussion about the design of the research in relation to the objective, procedure and approach of the problem. Next, the population and the delimitation of the sample are highlighted. In the third section we present the research construct and the form of data collection. Finally, in the fourth section the procedures used during data analysis are exposed.

\subsection{Research Design}

In relation to the research objective, the study is classified as descriptive once it evaluates the association of social disclosure with the market value of companies, of the environmental disclosure with the market value of companies and socio-environmental disclosure with the market value of Brazilian companies with high environmental impact. Regarding the procedures, the study is characterized as documentary, since the data related to the socio-environmental disclosure were collected from the following reports: sustainability report, annual report, standardized financial statements, explanatory notes, independent auditor's reports, fiscal council opinion, audit committee report and reference form, as well as data related to the market value of the companies collected through the Economática ${ }^{\circledR}$ database. Finally, in relation to the approach of the problem, the study is classified as predominantly quantitative, since it uses the techniques of descriptive statistics, scalar games, vector games and the ordinal correlation coefficient (Kendall) to reach the proposed goal.

\subsection{Population and Sample}

The study population corresponds to the 48 companies in the areas of extraction and treatment of minerals, to the metallurgical industry, to the paper and pulp industry, to the leather and furs industry, to the chemical industry and to transport, terminals, warehouses and commerce companies of the São Paulo Stock Exchange (BM\&FBovespa), which are defined as having a high environmental impact, according to Law No. 10.165, dated December 27, 2000. Four of these were excluded because they were controlled by other companies in the sample, 5 were eliminated because they were in judicial recovery during the analyzed period and 15 were excluded because they did not present all the necessary information for the calculation of the socio-environmental disclosure index and market value. Thus, the sample consisted of 24 companies.

\subsection{Research and Data Collection Construct}

This section is structured in two subdivisions: the construct (of the research and data collection) of the level of social and environmental disclosure of companies and the construct (of research and data collection) of the market value index. Such division is pertinent since such variables were collected in different ways and sources. 


\subsubsection{Level of Social and Environmental Disclosure}

The Rover metric (2013) was used in order to measure the level of social, environmental and socio-environmental disclosure of the organizations of the sample. This metric was chosen because its author is one of the main researchers on the topic of "socio-environmental disclosure" in Brazil and she constructed the metric based on 20 relevant national and international studies in the literature on the topic.

Table 1 shows the four social categories of the Rover metric (2013), with their respective social subcategories adapted to the data collection of the present research regarding the level of social disclosure.

Table 2 presents the Rover metric (2013) in relation to the environmental categories and their subcategories adapted to this research.

It should be noted that the Rover metric is composed of 40 environmental subcategories and 40 social subcategories. Thus, there was a need for adaptations, since, unlike Rover's (2013) research, this study was not concerned with the number of times the information was disclosed, but whether the information was evidenced by the company or not.

To measure each of the adapted subcategories and presented in Tables 1 and 2, we chose to use linear weighting, since for this weighting format, the higher the quality of information, the greater the weight assigned to it. Table 3 summarizes the values applied to each type of information.

The criteria presented in Table 3 sought to quantify the social and environmental subcategories in the following documents: Standardized Financial Statements (Balance Sheet, Statement of Changes in Shareholders' Equity, Statement of Cash Flows, Statement of Income for the Year and Statement of Value Added) Notes to the Financial Statements, Independent Auditor's Report, Fiscal Council's Report, Audit Committee's Report, Sustainability Report, Annual Report and Reference Form (item 7.8). It is worth noting that, in order to search for such information in the cited documents, we used NVivo software, which searches through semantic words. After the sections containing the semantic words were located, the analysis was performed through the NVivo software regarding the type of information. If the information was of a qualitative nature, the linear weighting assigned was ' 1 ', if non-monetary quantitative '2' and in case of monetary quantitative '3', according to Table 3.

Finally, to quantify the social categories $\left(s_{1}, s_{2}, s_{3}\right.$ and $\left.s_{4}\right)$ and environmental categories $\left(a_{1}, a_{2}, a_{3}, a_{4}, a_{5}, a_{6}, a_{7}, a_{8}\right.$ and $\left.a_{9}\right)$ presented in Tables 1 and 2, the division of the amount of information associated with each category was conducted for the maximum amount that it could achieve, as it was conducted by Rover (2013). It is important to emphasize that before calculating the rankings of the companies, according to the level of social, environmental and socio-environmental disclosure, the data were normalized for the formation of payment matrices. The normalization was done by dividing each value obtained by the companies by the maximum of the group in each criterion, i.e., $\overline{x_{i, j}}=\frac{x_{i, j}}{\max _{j} x_{i, j}}$, where $i$ is the company and $j$ the criterion. 
Table 1 - Metrics for the analysis of social disclosure.

(Source: Adapted from Rover (2013)).

\begin{tabular}{|c|c|}
\hline Categories & Subcategories \\
\hline \multirow{14}{*}{ Community $\left(s_{1}\right)$} & Volunteering programs \\
\hline & Sponsoring public health projects \\
\hline & Relations with indigenous peoples / \\
\hline & Relations with quilombola peoples \\
\hline & Sponsoring conferences or seminars or exhibitions or campaigns \\
\hline & Donations of resources to public entities or OSCIP \\
\hline & (Civil Society Organization for Public Interest) \\
\hline & Supporting education \\
\hline & Giving housing support / food support \\
\hline & Supporting culture \\
\hline & Supporting sports activities \\
\hline & Relationship with stakeholders \\
\hline & Decisions or fines related to the community in which it operates \\
\hline & Investments of a social character \\
\hline \multirow{5}{*}{ Diversity $\left(s_{2}\right)$} & Number of women or minorities in the workforce \\
\hline & Occupation of women or minorities in management positions \\
\hline & Proportion of salary between men and women \\
\hline & Hiring people with disabilities \\
\hline & Non-discrimination policies against minorities \\
\hline \multirow{5}{*}{ Product, services and consumers $\left(s_{3}\right)$} & Quality Program - ISO 9000 / Quality Program - ISO 9.001 \\
\hline & Product Innovation (Research \& Development) \\
\hline & Products in accordance with safety standards \\
\hline & Consumer satisfaction or dissatisfaction \\
\hline & Unfair competition or trust practices \\
\hline \multirow{19}{*}{ Relations with employees $\left(s_{4}\right)$} & $\begin{array}{l}\text { Number of employees / Employees' length of service / } \\
\text { Age group of employees }\end{array}$ \\
\hline & Payment of employees (average or total) \\
\hline & Trade union relations or with class agencies \\
\hline & Programs to encourage culture \\
\hline & Development of recreational or sports activities \\
\hline & Employee Education / Employee Training \\
\hline & $\begin{array}{l}\text { Health in the workplace / Hygiene in the workplace / } \\
\text { Safety in the workplace }\end{array}$ \\
\hline & Accidents at work / Occupational diseases / Absenteeism / Deaths \\
\hline & Retirement or supplementary pension plans \\
\hline & Childcare aid for children of employees / \\
\hline & Scholarship for children of employees \\
\hline & Maternity Support / Paternity Support \\
\hline & Profit sharing \\
\hline & Turnover rate / Resignation policy \\
\hline & Employee participation in managerial decisions \\
\hline & Job satisfaction / Employee motivation \\
\hline & Child labor or forced labor or analogous to slavery \\
\hline & Investments in managerial development \\
\hline & Value added per employee \\
\hline
\end{tabular}


Table 2 - Metrics for the analysis of environmental disclosure.

(Source: Adapted from Rover (2013)).

\begin{tabular}{|c|c|}
\hline Categories & Subcategories \\
\hline \multirow{8}{*}{ Environmental policies $\left(a_{1}\right)$} & $\begin{array}{l}\text { Statement of current policies / } \\
\text { Statement of current practices or actions }\end{array}$ \\
\hline & Setting goals / Establishing environmental objectives \\
\hline & $\begin{array}{l}\text { Environmental certification / } \\
\text { Compliance with environmental laws and regulations }\end{array}$ \\
\hline & Partnerships, councils, environmental forums \\
\hline & Environmental awards / \\
\hline & Participation in environmental indexes \\
\hline & Participation in environmental organizations \\
\hline & Environmental relationship with stakeholders \\
\hline \multirow{5}{*}{$\begin{array}{l}\text { Environmental management } \\
\text { and auditing }\left(a_{2}\right)\end{array}$} & Environmental risk management \\
\hline & ISO 14.000 \\
\hline & Environmental Performance Indicators \\
\hline & Environmental review or environmental audits \\
\hline & Evaluation including independent opinion \\
\hline \multirow{5}{*}{ Environmental impacts $\left(a_{3}\right)$} & Waste / Residue \\
\hline & Leaks / Spills / Land used \\
\hline & Repairs to environmental damage \\
\hline & Emission of Greenhouse Gases (GHG) \\
\hline & Emission of substances that deplete the ozone layer \\
\hline \multirow{4}{*}{ Ecological products $\left(a_{4}\right)$} & Development of ecological products \\
\hline & Recycling \\
\hline & Packaging process (reuse of packaging) \\
\hline & Efficient use or reuse of water \\
\hline \multirow{4}{*}{ Energetic resources $\left(a_{5}\right)$} & Development or exploitation of new energy sources \\
\hline & Use of material waste for the production of energy \\
\hline & Consumption of energy from renewable sources \\
\hline & Company's efforts to reduce energy consumption \\
\hline \multirow{2}{*}{$\begin{array}{l}\text { Environmental education } \\
\text { and research }\left(a_{6}\right)\end{array}$} & Environmental education (internally or community) \\
\hline & Support for research related to the environment \\
\hline \multirow{3}{*}{ Carbon credits market $\left(a_{7}\right)$} & Clean Development Mechanism Projects (CDM) \\
\hline & Reduced Emissions Certificates (RECs) \\
\hline & Carbon credits or carbon offsets \\
\hline \multirow{3}{*}{$\begin{array}{l}\text { Sustainability and } \\
\text { biodiversity }\left(a_{8}\right)\end{array}$} & Mention related to sustainable development \\
\hline & Forest management or reforestation \\
\hline & $\begin{array}{l}\text { Preservation of biodiversity / } \\
\text { Preservation of natural resources }\end{array}$ \\
\hline \multirow{7}{*}{$\begin{array}{l}\text { Environmental financial } \\
\text { information }\left(a_{9}\right)\end{array}$} & Environmental investments \\
\hline & Environmental revenues \\
\hline & Environmental costs / Environmental expenditures \\
\hline & Liabilities or environmental contingencies \\
\hline & $\begin{array}{l}\text { Accounting practices of environmental items } \\
\text { - measurement criteria }\end{array}$ \\
\hline & Environmental insurance \\
\hline & Intangible environmental assets \\
\hline
\end{tabular}


Table 3 - Criteria for linear weighting.

(Source: Adapted from Rover (2013)).

\begin{tabular}{l|c}
\hline \multicolumn{1}{c|}{ Criteria } & Linear \\
\hline No disclosure & 0 \\
\hline Qualitative disclosures & 1 \\
\hline Non-monetary quantitative disclosures & 2 \\
\hline Monetary quantitative disclosures & 3 \\
\hline
\end{tabular}

\subsubsection{Market Value of Companies}

The word value, in the accounting, economic and legal context is very broad, which leads to it having different meanings (Neiva, 1999). According to Neiva (1999) it is necessary to use some terms to better explain the meaning of value, such as: real value, current value, intrinsic value, book value, settlement value, market value, among others.

The market value of an organization in the capital market refers to the value that the investor is willing to pay for the company (Chaves \& Pimenta Junior, 2013). Regarding this, Santos, Araújo \& Leite Filho (2016) mention that investors generally pay for the organization according to the expectations generated by them through the information available in the market.

The variable used in this research to measure the companies' market value was the share price multiplied by the number of shares on December 31. The date of December 31 was chosen, since there is a need to use a moment in which all the information evidenced has already been absorbed by the market. Therefore, due to the use of reports that are not mandatory by law, which do not have a specific period for disclosure, it was decided to carry out the market value analysis on December 31 and December of the year following the report.

In order to analyze the association between the level of social, environmental and socio-environmental disclosure with market value, the market value of 2014 was used in relation to the disclosure of 2013 and the market value of 2015 in relation to the disclosure of 2014. This is justified since the report is released during the following year. The information regarding the market value was collected in the Economática ${ }^{\circledR}$ database.

\subsection{Data Analysis Procedures}

In this section we present the techniques used in the research to achieve the proposed objective. In the first moment, the ranking conducted by means of scalar and vector games is highlighted. Afterwards, we present Kendall's correlation, which was used to verify the association between the study variables.

It is worth mentioning the procedures of game theory, a technique that according to Mármol \& Monroy (1999), provides a unified framework in economic analysis contributing to the modeling of economic behavior and helping decisions in the optimization of a single objective. According 
to Zeleny (1982), games in which the payments received by players are represented by vectors and not by scalars are called vector games, multicriteria games or games with multiple payments. Vector games differ from scalar games because of the payment structure, which is enough so that many of the results of scalar games can not be extended directly to vector games because there is no order among vector payments, resulting in new concepts and solution procedures (Monroy \& Mármol, 1999; Puerto, Hinojosa, Mármol, Monroy \& Fernández, 1999; Monroy, Mármol \& Rubiales, 2008).

\subsubsection{Preliminaries of Game Theory}

\section{Scalar games}

Let $P=\left(a_{i j}\right) ; i=1, \ldots, n, j=1, \ldots, m$ be the payment matrix of a zero-sum two-personal game and the mixed strategy sets for both player I and player II are respectively:

$$
\begin{aligned}
& X=\left\{x \in R^{n} \mid \sum_{i=1}^{n} x_{i}=1, x_{i} \geq 0, i=1, \ldots, n\right\} \\
& Y=\left\{y \in R^{m} \mid \sum_{j=1}^{m} y_{j}=1, y_{j} \geq 0, j=1, \ldots, m\right\}
\end{aligned}
$$

The expected payment of the game when player I uses his mixed strategy $x=\left(x_{1}, \ldots, x_{n}\right)$ and player II uses his mixed strategy $y=\left(y_{1}, \ldots, y_{n}\right)$, is given by:

$$
v(x, y)=x^{t} \mathrm{Py}=\sum_{i=1}^{n} \sum_{j=1}^{m} x_{i} a_{i j} y_{j} \forall x \in X, \forall y \in Y
$$

For each mixed strategy, $x \in X$, the level of security for player $\mathrm{I}$ is $v(x)=\min _{y \in Y} x^{t} \mathrm{Py}$. This player looks for strategies that provide him/her with the best level of security, i.e. strategies $x \in X$ that maximize $v(x)$. To him/her this must solve the problem $\max _{x \in X} v(x)$ s.t. $v(x)=\min _{1 \leq j \leq m} \sum_{i=1}^{n} x_{i} a_{i j}$. By making the change and variable $v=\min _{1 \leq j \leq m} \sum_{i=1}^{n} x_{i} a_{i j}$, the solution of the following equivalent linear problem provides the optimal security strategies:

$$
\begin{array}{ll}
\max & v \\
\text { s.t. } & \sum_{i=1}^{n} x_{i} a_{i j} \geq v, j=1, \ldots, m \\
& \sum_{i=1}^{n} x_{i}=1, x_{i} \geq 0, i=1, \ldots, n
\end{array}
$$




\section{Vector Games}

Let a two-personal game of zero sum be in normal form and let $P=\left(a_{i j}\right) ; 1 \leq i \leq n, 1 \leq j \leq m$ be the matrix of payments of the game. Each element $a_{i j}$ of the matrix is a vector of $k$ dimension (Fernández \& Puerto, 1996):

$$
a_{i j}=\left(a_{i j}(1), a_{i j}(2), \ldots, a_{i j}(k)\right) \in R^{k}
$$

which determines $k$ matrices of $n \times m$ order in the form:

$$
P(p)=\left(a_{i j}(p)\right) 1 \leq p \leq k ; 1 \leq i \leq n ; 1 \leq j \leq m
$$

The expected payment of the game when players choose their mixed strategies $x \in X$ and $y \in Y$, respectively, is given by:

$$
v(x, y)=x^{t} P y=\left(v_{1}(x, y), \ldots, v_{k}(x, y)\right)
$$

where:

$$
v_{p}(x, y)=x^{t} P(p) y ; p=1, \ldots, k
$$

For each $x \in X$ strategy of player I the security level vector for that player is the payment that can guarantee in each scalar game induced by the vector game $v(x)=\left(v_{1}(x), \ldots, v_{k}(x)\right)$ where $v_{p}(x)=\min _{y \in Y} v_{p}(x, y)=\min _{y \in Y} x^{t} P(p) y$.

The optimal strategies and their associated security level vector are obtained from the following linear multi-objective problem

$$
\begin{array}{ll}
\max & v_{1}, \ldots, v_{k} \\
\text { s.t. } & x^{t} P(p) \geq\left(v_{p}, \ldots, v_{p}\right) ; p=1, \ldots, k \\
& \sum_{i=1}^{n} x_{i}=1 ; x_{i} \geq 0
\end{array}
$$

A classic procedure for obtaining solutions to multiobjective problems is the programming by compromise (Zeleny, 1976). It is based on considering the points closest to an ideal point of reference. In this case we consider the scalar problem that minimizes the distance, considering the $L_{1}$ metric, between the security level vector $v(x)=\left(v_{1}(x), \ldots, v_{k}(x)\right)$ and an ideal payment vector $v^{*}(x)=\left(v_{1}^{*}, \ldots, v_{k}^{*}\right)$, where $v_{p}^{*}=\max _{x \in X} v_{p}(x), p=1, \ldots, k$,

$$
\begin{array}{ll}
\min & {\left[\frac{v_{1}^{*}-v_{1}(x)}{v_{1}^{*}}\right]+\left[\frac{v_{2}^{*}-v_{2}(x)}{v_{2}^{*}}\right]+\cdots+\left[\frac{v_{k}^{*}-v_{k}(x)}{v_{k}^{*}}\right]} \\
\text { s.t. } & x^{t} P(p) \geq\left(v_{p}, \ldots, v_{p}\right) ; p=1, \ldots, k \\
& \sum_{i=1}^{n} x_{i}=1 ; x_{i} \geq 0
\end{array}
$$




\subsubsection{Construction of the Model}

In the current context, Game Theory has been applied in several areas of knowledge, such as administration, biology, political sciences, law and economics (Fiani, 2004), it has also has been developed within the area of Operational Research (Dimand \& Dimand, 1996). According to Brandt, Fischer, Harrenstein \& Shoham (2009), Kreuzberg (2013), Kroenke (2014) and Rubiales, Monroy \& Mármol (2017) it can be used today as a ranking technique.

In this research, the scalar games technique was used for the development of rankings referring to social disclosure and rankings related to environmental disclosure. In addition, in order to rank companies according to the level of socio-environmental disclosure, the technique of vector games was used. For Leoneti (2016), to choose multicriteria decision methods involves the observation of key factors, given the variability of methods, such as ability with method, need for conflict minimization and need for transparency. The methods may be sensitive when small variations occur in the input and alert data that different classifications can be obtained when different multicriteria decision methods are applied to obtain rankings.

According to Kroenke (2014), the scoring technique through scalar games is used when there is only one payment per indicator, or allotments of indicators. In this study, they are represented by means of allotments of levels of social and environmental disclosure when analyzed separately. In the scalar game related to social disclosure, four (4) strategies were assumed, each being a social indicator: community $\left(s_{1}\right)$, diversity $\left(s_{2}\right)$, "product, services and consumers" $\left(s_{3}\right)$ and relationships with employees $\left(s_{4}\right)$. Nine $(9)$ strategies were attributed to the scalar game related to the environmental disclosure given by the indicators: environmental policies $\left(a_{1}\right)$, environmental management and auditing $\left(a_{2}\right)$, environmental impacts $\left(a_{3}\right)$, ecological products $\left(a_{4}\right)$, energetic resources $\left(a_{5}\right)$, environmental education and research $\left(a_{6}\right)$, carbon credits market $\left(a_{7}\right)$, sustainability and biodiversity $\left(a_{8}\right)$ and environmental financial information $\left(a_{9}\right)$.

According to Kreuzberg (2013), in order to find the solution to scalar games and thus elaborate the rankings by means of such technique, it is necessary to construct the matrix of payments, in which the strategies of the Player I will be distributed in the lines and the Strategies of the Player II, in the columns. The following are two payment matrices ( $P_{S}$ : social; $P_{A}$ : environmental), each with a single payment per line and column.

$$
P_{S}=\left(\begin{array}{cccc}
s_{1,1} & s_{1,2} & \cdots & s_{1,4} \\
s_{2,1} & s_{2,2} & \cdots & s_{2,4} \\
\vdots & \vdots & \ddots & \vdots \\
s_{24,1} & s_{24,2} & \cdots & s_{24,4}
\end{array}\right) ; P_{A}=\left(\begin{array}{cccc}
a_{1,1} & a_{1,2} & \cdots & a_{1,9} \\
a_{2,1} & a_{2,2} & \vdots & \vdots \\
\cdots & a_{2,9} & \ddots & \vdots \\
a_{24,1} & a_{24,2} & \cdots & a_{24,9}
\end{array}\right)
$$

In the matrix of payments, Player I (Sector) makes its choices in light of the strategies arranged in the lines which, in this research, refer to the companies of the sample. On the other hand, Player II (Nature) makes its choices based on the gains presented in the columns which, in a first moment in this study, are formed by the indicators of the level of social disclosure and, in a second moment, by the indicators of the level of environmental disclosure. 
Games against nature are locked against some entity that is not specifically a rational human player, but rather a game from a "point of view in which the decision maker plays against the diabolic nature" (Luce \& Raiffa, 1957, p. 279). Ostolaza (1969, p. 10) states that "Nature is passive, in the sense that it does not affect neither gains nor losses of the game".

The verification of the optimal strategies in the scalar game for Player I is obtained by solving the Linear Programming Problem (LPP) (Magro, Gorla, Kroenke \& Hein, 2015). The following LPP brings the primal model of the game that the 24 companies play with the four social indicators:

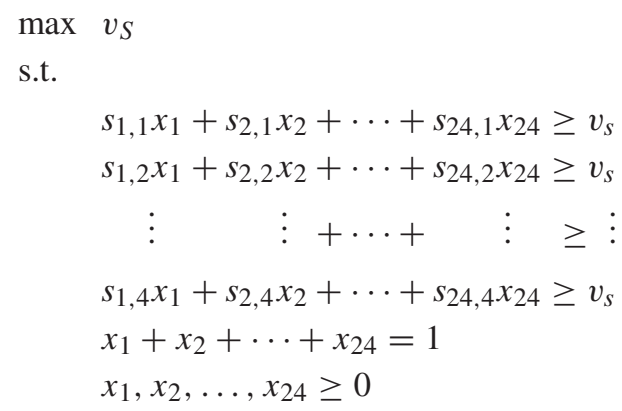

In a similar way, the PPL was constructed, and it models the primal game established between the 24 companies of the sample, against the nine (9) environmental indicators:

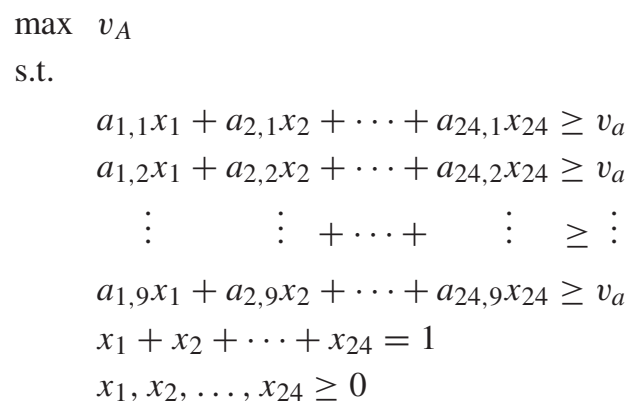

In this research the LPPs were solved through PLM 3.0 software (Programação Linear Mista v.3.0). After checking the optimal strategy suggested: pure or mixed for Player I in the first round, the company (pure strategy) or companies (mixed strategy) that are presented as optimal strategies were removed from the problem. In a recurrent way, the LPP was successively executed until the complete formation of the ranking.

For the construction of the rankings of companies, according to the levels of social and environmental disclosure, the vector games were used, taking two allotments of indicators: social and environmental. Vector games are used when the payment is not unique, that is, there are two or more payments. In the research, the allotments of social and environmental indicators were assumed as possible strategies and payments as their indicators, i.e., four (4) payments for the social strategy and nine (9) payments in the environmental strategy.

The following matrix refers to the vector game of the 24 companies established against two strategies: an environmental one and a social one. The social strategy brings 4 payments, given 
by indicators: community $\left(s_{1}\right)$, diversity $\left(s_{2}\right)$, "product, services and consumers" $\left(s_{3}\right)$ and relations with employees $\left(s_{4}\right)$. The environmental strategy has 9 payments, given by indicators: environmental policies $\left(a_{1}\right)$, environmental management and auditing $\left(a_{2}\right)$, environmental impacts $\left(a_{3}\right)$, ecological products $\left(a_{4}\right)$, energetic resources $\left(a_{5}\right)$, environmental education and research $\left(a_{6}\right)$, carbon credits market $\left(a_{7}\right)$, sustainability and biodiversity $\left(a_{8}\right)$ and environmental financial information $\left(a_{9}\right)$. The multiple payment matrix scheme is shown below:

$$
P=\left(\begin{array}{cc}
\left(s_{1,1}, s_{1,2}, \ldots, s_{1,4}\right) & \left(a_{1,1}, a_{1,2}, \ldots, a_{1,9}\right) \\
\left(s_{2,1}, s_{2,2}, \ldots, s_{2,4}\right) & \left(a_{2,1}, a_{2,2}, \ldots, a_{2,9}\right) \\
\vdots & \vdots \\
\left(s_{24,1}, s_{24,2}, \ldots, s_{24,4}\right) & \left(a_{24,1}, a_{24,2}, \ldots, a_{24,9}\right)
\end{array}\right)
$$

In a similar way to the scalar game, in the matrix presented in relation to the vector game Player I (companies of the sector) makes its choices in light of the strategies presented in the lines, while Player II (allotments of indicators) makes its choices in light of the strategies distributed in the columns. However, by presenting more than one allotment of indicators, the Linear Programming Problem used to verify the optimal strategies is adjusted according to what was modeled by Kroenke, Hein \& Wilhelm (2015).

$$
\begin{array}{ll}
\max & v_{1}, \ldots, v_{k} \\
\text { s.t. } & \\
& x^{t} P(p) \geq\left(v_{1}, \ldots, v_{k}\right) ; p=1, \ldots, k ; \\
& k=1, \ldots, n \text { (allotments of indicators) } \\
& \sum_{i=1}^{n} x_{i}=1 ; x_{i} \geq 0
\end{array}
$$

Specifically for this game we consider that $k=2$, where the first allotment of indicators has 4 elements, which are taken as payments and the second one 9 indicators, that is, considered in the research as payments. The model used is described below:

$$
\begin{array}{ll}
\max & v_{S}, v_{A} \\
\text { s.t. } & \\
& s_{1,1} x_{1}+s_{2,1} x_{2}+\cdots+s_{24,1} x_{24} \geq v_{S} \\
& s_{1,2} x_{1}+s_{2,2} x_{2}+\cdots+s_{24,2} x_{24} \geq v_{S} \\
\vdots & \vdots+\cdots+\quad \vdots \quad \geq \\
& s_{1,4} x_{1}+s_{2,4} x_{2}+\cdots+s_{24,4} x_{24} \geq v_{S} \\
a_{1,1} x_{1}+a_{2,1} x_{2}+\cdots+a_{24,1} x_{24} \geq v_{A} \\
a_{1,2} x_{1}+a_{2,2} x_{2}+\cdots+a_{24,2} x_{24} \geq v_{A} \\
\vdots \quad \vdots \quad \\
\vdots \\
a_{1,9} x_{1}+a_{2,9} x_{2}+\cdots+a_{24,9} x_{24} \geq v_{A} \\
x_{1}+x_{2}+\cdots+x_{24}=1 \\
x_{1}, x_{2}, \ldots, x_{24} \geq 0
\end{array}
$$


Unlike Kroenke, Hein \& Wilhelm (2015), who adapted this LPP to make use of the value of the information found by means of the variance of the normalized data of each allotment of indicators for the construction of the objective function, in this research the multi-objective optimization was used by means of global criterion with the normalized data. Multi-objective optimization refers to a problem in which there are two or more objectives to be optimized (maximized or minimized) simultaneously (Azuma, 2011). According to Antunes \& Alves (2012), this optimization problem is generally used since in real problems there are usually multiple optics to evaluate the merits of the permissible solutions.

It should be mentioned that the objectives to be optimized in multi-objective optimization problems are usually conflicting, since there is usually not a single optimal solution that simultaneously meets all the objectives (Amorim, Romero \& Mantovani, 2009). In light of this type of problem Rao (1996) described the Global Criteria Method, in which the optimal solution is evidenced by minimizing a pre-established criterion. According to Carmelossi (2014) by means of such a method it is possible to obtain the closest solution possible to the ideal solution.

For the linear problem of the previous bi-criteria game, the problem that gives the compromise solution is:

$$
\begin{array}{cc}
\min & {\left[\frac{v_{S}^{*}-v_{S}(x)}{v_{S}^{*}}\right]+\left[\frac{v_{A}^{*}-v_{A}(x)}{v_{A}^{*}}\right]} \\
\text { s.t. } & \\
s_{1,1} x_{1}+s_{2,1} x_{2}+\cdots+s_{24,1} x_{24} \geq v_{S} \\
s_{1,2} x_{1}+s_{2,2} x_{2}+\cdots+s_{24,2} x_{24} \geq v_{S} \\
\vdots \quad \vdots+\cdots+\quad \vdots \quad \geq \\
s_{1,4} x_{1}+s_{2,4} x_{2}+\cdots+s_{24,4} x_{24} \geq v_{S} \\
a_{1,1} x_{1}+a_{2,1} x_{2}+\cdots+a_{24,1} x_{24} \geq v_{A} \\
a_{1,2} x_{1}+a_{2,2} x_{2}+\cdots+a_{24,2} x_{24} \geq v_{A} \\
\vdots \quad \vdots \quad+\cdots+\quad \vdots \\
\quad \vdots \quad \geq \\
a_{1,9} x_{1}+a_{2,9} x_{2}+\cdots+a_{24,9} x_{24} \geq v_{A} \\
x_{1}+x_{2}+\cdots+x_{24}=1 \\
x_{1}, x_{2}, \ldots, x_{24} \geq 0
\end{array}
$$

As in scalar games, the multi-objective LPP was solved through PLM v.3.0. In addition, the form of ranking was the same one adopted for the scalar games, since the company or the companies that presented themselves as optimal strategies were removed from the problem, conducting it again until the complete formation of the rankings.

\subsubsection{Kendall Correlation}

In order to reach the objective of the study of evaluating the degree of association between social disclosure and market value, environmental disclosure with market value and socio-environmental disclosure with market value, respectively, the statistical method was adopted by Kendall's correlation. We chose such metrics because, according to Martins \& Theóphilo (2007), it measures the degree of association between two sets of points. 
According to Kaveski (2013) Kendall's correlation coefficient is defined by three steps, the first being the statistical test $\mathrm{S}$, which measures the monotonic dependence between the variable $\mathrm{Y}$ in relation to the variable $X$. In order to verify such dependency, the difference between the number of discordant pairs by the number of matching pairs is calculated.

The second step refers to the calculation that determines the Kendall correlation coefficient, given by:

$$
\tau=\frac{S}{\frac{n(n-1)}{2}}
$$

where:

$\tau$ the Kendall correlation coefficient;

$S$ relation of the orders found (monotonous dependence); and

$n$ sample size.

Finally, the last step regarding this technique concerns the measurement of the significance of the Kendall correlation coefficient, which is evaluated by means of a two-tailed hypothesis test that checks if S is statistically different from zero (Kaveski, 2013). As mentioned by Martins \& Theóphilo (2007), Kendall's correlation coefficient can vary from -1 to 1 , in which values close to 1 indicate concordance between variables, while values close to -1 indicate aversion of their values. It should be noted that the Statistical Package for the Social Sciences (SPSS) was used to perform the Kendall correlation method.

\section{PRESENTATION AND ANALYSIS OF RESULTS}

This chapter presents the results obtained in the study, whose purpose was to establish the association of social, environmental and socio-environmental disclosure with the market value of Brazilian companies with high environmental impact. To do so, it was necessary to divide this chapter into two sections, the first section presenting the social, environmental, socio-environmental and market value rankings, and in the second section the results obtained through Kendall's correlation.

\subsection{Rankings}

This section presents the rankings formed by the levels of social, environmental, socio-environmental disclosure and the rankings referring to the market value indicator. For this the section was divided into four subsections. In the first and second subsection, the company's 2013 and 2014 rankings are presented according to the level of social disclosure and the level of environmental disclosure, respectively, which were obtained through the scalar games technique. The following subsection presents the 2013 and 2014 rankings referring to the level of socioenvironmental disclosure of companies, and these were obtained through the technique of vector games. Finally, in the last subsection, the 2014 and 2015 rankings of the market value indicator are presented, which were elaborated by means of the descending order of such variable. 
The data that formed the payment matrices for social, environmental and socio-environmental disclosure levels for 2013 are shown in Table 4.

Table 4 - Data of payment matrices of social, environmental and socio-environmental disclosure level of 2013. (Source: Research data).

\begin{tabular}{|c|c|c|c|c|c|c|c|c|c|c|c|c|c|}
\hline \multirow{2}{*}{ Companies } & \multicolumn{4}{|c|}{ Social Restrictions } & \multicolumn{9}{|c|}{ Environmental Restrictions } \\
\hline & $s_{1}$ & $s_{2}$ & $s_{3}$ & $s_{4}$ & $a_{1}$ & $a_{2}$ & $a_{3}$ & $a_{4}$ & $a_{5}$ & $a_{6}$ & $a_{7}$ & $a_{8}$ & $a_{9}$ \\
\hline PARANAPANEMA $\left(x_{1}\right)$ & 0.15 & 0.55 & 0.20 & 0.48 & 0.42 & 0.50 & 0.13 & 0.80 & 0.22 & 0.00 & 0.00 & 0.29 & 0.30 \\
\hline PANATLA & 0.00 & 0.00 & 0.00 & 0.02 & 0.00 & 0.00 & .00 & 0.00 & 0.00 & 0.00 & 0.00 & 0.00 & 0.00 \\
\hline COSA & 0.56 & 1.00 & 1.00 & 0.86 & 0.84 & 0.63 & 0.53 & 1.00 & 0.78 & 0.50 & 0.00 & 0.57 & 0.90 \\
\hline PET & .00 & 0.00 & 0.00 & 0.05 & 0.11 & 0.13 & 0.00 & 0.00 & 0.00 & 0.17 & 0.00 & 0.14 & 0.00 \\
\hline $\mathrm{P}$ & 74 & 0.73 & 0.30 & 0 & 0 & 0.75 & 1.00 & 0.80 & 0.44 & 0.50 & 0.00 & 0.29 & 0.60 \\
\hline QG & 8 & 0.91 & 0.80 & 0.98 & 0 & 0 & 7 & 0.40 & 0.00 & 1.00 & 0,00 & 0.57 & 70 \\
\hline UL & 3 & 0.00 & 0.40 & 031 & 0.42 & 0.50 & .33 & 0.40 & 0.11 & 00.0 & 0.33 & .00 & 0.70 \\
\hline FEK & 33 & 0.73 & 0.40 & 0.67 & 0.42 & 0.13 & 0.53 & 0.80 & 0.67 & 0.17 & 0.00 & 0.86 & 0.30 \\
\hline BR I & .11 & 0.00 & 0.00 & 0.12 & 0.00 & 0.00 & 0.00 & 0.00 & 0.00 & 0.00 & 0.00 & 0.00 & 0.00 \\
\hline $\mathrm{CRE}$ & .00 & 0.00 & 0.00 & 0.21 & 0.00 & 0.00 & 0.00 & 0.00 & 0.00 & 0.00 & 0.00 & 0.00 & 0.00 \\
\hline $\operatorname{DIMED}\left(x_{11}\right)$ & .04 & 0.00 & 0.00 & 0.07 & 0.11 & 0.00 & 0.00 & 0.00 & 0.00 & 0.00 & 0.00 & 0.00 & 0.00 \\
\hline PROFARMA $\left(x_{12}\right)$ & .41 & 0.00 & 0.10 & 0.17 & 0.00 & 0.00 & 0.00 & 0.00 & 0.00 & 0.00 & 0.00 & 0.00 & 0.00 \\
\hline RAIADROC & .22 & 0.18 & 0.00 & 0.12 & 0.00 & 0.00 & 0.13 & 0.00 & 0.00 & 0.00 & 0.00 & 0.00 & 0.00 \\
\hline BRADESPAR $\left(x_{14}\right)$ & 0.04 & 0.00 & 0.00 & 0.00 & 0.11 & 0.00 & 0.00 & 0.00 & 0.11 & 0.00 & 0.00 & 0.14 & 0.00 \\
\hline $\operatorname{VALE}\left(x_{15}\right)$ & 00 & 0.73 & 0.50 & 88 & 1.00 & 0.88 & 1.00 & 0.40 & 1.00 & .67 & 0.33 & 0.86 & 0.40 \\
\hline CELUL IRANI $\left(x_{16}\right)$ & 0.56 & 0.82 & 0.90 & 0.81 & 0.58 & 1.00 & 0.87 & 0.60 & 0.67 & 1.00 & 1.00 & 0.86 & 0.90 \\
\hline FIBRIA $\left(x_{17}\right)$ & 0.63 & 0.36 & 0.50 & 0.67 & 1.00 & 0.63 & 0.47 & 0.20 & 0.22 & 0.83 & 0.00 & 1.00 & 0.10 \\
\hline $\operatorname{KLABIN}\left(x_{18}\right)$ & 0.41 & 0.45 & 0.30 & 0.31 & 0.89 & 0.63 & 0.33 & 0.20 & 0.33 & 0.33 & 0.00 & 0.71 & 0.40 \\
\hline BRASKEM $\left(x_{19}\right)$ & 0.67 & 0.55 & 0.60 & 0.67 & 0.79 & 0.75 & 0.93 & 0.80 & 0.56 & 0.67 & 0.00 & 0.57 & 1.00 \\
\hline ELEKEIROZ $\left(x_{20}\right)$ & 0.48 & 0.45 & 0.30 & 0.86 & 0.32 & 0.63 & 0.53 & 0.00 & 0.11 & 0.67 & 0.00 & 0.29 & 0.60 \\
\hline NATURA $\left(x_{21}\right)$ & 0.78 & 0.82 & 1.00 & 1.00 & 0.89 & 0.38 & 0.53 & 0.60 & 0.44 & 0.33 & 1.00 & 0.43 & 0.40 \\
\hline VITALYZE.ME $\left(x_{22}\right)$ & 0.11 & 0.00 & 0.00 & 0.00 & 0.00 & 0.00 & 0.13 & 0.00 & 0.00 & 0.00 & 0.00 & 0.00 & 0.00 \\
\hline $\operatorname{UNIPAR}\left(x_{23}\right)$ & 0.00 & 0.00 & 0.30 & 0.19 & 0.00 & 0.13 & 0.00 & 0.00 & 0.00 & 0.00 & 0.00 & 0.00 & 0.30 \\
\hline GERDAU $\left(x_{24}\right)$ & 0.44 & 0.00 & 0.40 & 0.55 & 0.53 & 0.13 & 0.07 & 0.40 & 0.33 & 0.50 & 0.00 & 0.57 & 1.00 \\
\hline
\end{tabular}

In a similar way to the data presented in Table 5, the payment matrices and respective rankings of social, environmental and socio-environmental disclosure levels for 2014 were formed.

With the information previously mentioned, the resolution of the models to obtain the social, environmental and social-environmental rankings of the companies that will be presented in the next sections began.

Regarding the market value variable, Table 6 shows the descriptive statistics of the data used in this research. 
Table 5 - Data of payment matrices of the level of social, environmental and socio-environmental disclosure of 2014. (Source: Research data).

\begin{tabular}{|c|c|c|c|c|c|c|c|c|c|c|c|c|c|}
\hline \multirow{2}{*}{ Companies } & \multicolumn{4}{|c|}{ Social Restrictions } & \multicolumn{9}{|c|}{ Environmental Restrictions } \\
\hline & $s_{1}$ & $s_{2}$ & $s_{3}$ & $s_{4}$ & $a_{1}$ & $a_{2}$ & $a_{3}$ & $a_{4}$ & $a_{5}$ & $a_{6}$ & $a_{7}$ & $a_{8}$ & $a_{9}$ \\
\hline PARANAPANEMA $\left(x_{1}\right)$ & 0.13 & 0.55 & 0.33 & 0.44 & 0.35 & 0.67 & 0.13 & 0.50 & 0.33 & 0.00 & 0.00 & 0.29 & 0.23 \\
\hline PANATLANTICA $\left(x_{2}\right)$ & 0.00 & 0.00 & 0.00 & 0.06 & 0.00 & 0.00 & 0.00 & 0.00 & 0.00 & 0.00 & 0.00 & 0.00 & 0.00 \\
\hline $\operatorname{COSAN}\left(x_{3}\right)$ & 0.65 & 0.55 & 0.67 & 0.56 & 0.71 & 0.50 & 0.53 & 1.00 & 0.00 & 0.75 & 0.00 & 0.43 & 0.23 \\
\hline PETRORIO $\left(x_{4}\right)$ & 0.09 & 0.00 & 0.00 & 0.19 & 0.12 & 0.33 & 0.00 & 0.00 & 0.00 & 0.5 & 0.00 & 0.14 & 0.23 \\
\hline PETROBRAS $\left(x_{5}\right)$ & 0.74 & 1.00 & 0.78 & 1.00 & 0.76 & 1.00 & 0.93 & 0.83 & 0.67 & 1.00 & 0.33 & 0.57 & 0.38 \\
\hline QGEP PART $\left(x_{6}\right)$ & 0.39 & 0.73 & 0.78 & 0.77 & 0.59 & 0.50 & 0.33 & 0.50 & 0.50 & 0.50 & 0.00 & 0.14 & 0.31 \\
\hline ULTRAPAR $\left(x_{7}\right)$ & 0.52 & 0.00 & 0.56 & 0.40 & 0.47 & 0.83 & 0.33 & 0.67 & 0.17 & 0.50 & 0.33 & 0.14 & 0.54 \\
\hline FER HERINGER $\left(x_{8}\right)$ & 0.35 & 0.18 & 0.56 & 0.60 & 0.47 & 0.33 & 0.47 & 0.67 & 0.33 & 0.50 & 0.00 & 0.29 & 0.08 \\
\hline BR PHARMA $\left(x_{9}\right)$ & 0.13 & 0.00 & 0.00 & 0.06 & 0.00 & 0.00 & 0.00 & 0.00 & 0.00 & 0.00 & 0.00 & 0.00 & 0.00 \\
\hline CREMER $\left(x_{10}\right)$ & 0.09 & 0.00 & 0.00 & 0.21 & 0.00 & 0.00 & 0.00 & 0.00 & 0.00 & 0.00 & 0.00 & 0.00 & 0.00 \\
\hline $\operatorname{DIMED}\left(x_{11}\right)$ & 0.00 & 0.00 & 0.00 & 0.10 & 0.12 & 0.00 & 0.00 & 0.00 & 0.00 & 0.00 & 0.00 & 0.00 & 0.00 \\
\hline PROFARMA $\left(x_{12}\right)$ & 0.52 & 0.00 & 0.11 & 0.19 & 0.00 & 0.00 & 0.00 & 0.00 & 0.00 & 0.00 & 0.00 & 0.00 & 0.00 \\
\hline RAIADROGASIL $\left(x_{13}\right)$ & 0.04 & 0.00 & 0.11 & 0.15 & 0.00 & 0.00 & 0.00 & 0.00 & 0.00 & 0.00 & 0.00 & 0.00 & 0.00 \\
\hline BRADESPAR $\left(x_{14}\right)$ & 0.04 & 0.00 & 0.00 & 0.00 & 0.00 & 0.00 & 0.00 & 0.00 & 0.00 & 0.00 & 0.00 & 0.14 & 0.00 \\
\hline $\operatorname{VALE}\left(x_{15}\right)$ & 1.00 & 0.91 & 0.56 & 0.79 & 1.00 & 0.83 & 1.00 & 0.33 & 0.83 & 1.00 & 0.00 & 0.86 & 0.23 \\
\hline CELUL IRANI $\left(x_{16}\right)$ & 0.48 & 0.55 & 0.67 & 0.65 & 0.76 & 0.67 & 0.87 & 0.33 & 1.00 & 0.75 & 0.33 & 0.86 & 0.23 \\
\hline FIBRIA $\left(x_{17}\right)$ & 0.61 & 0.45 & 0.67 & 0.67 & 0.76 & 0.67 & 0.27 & 0.33 & 0.67 & 0.50 & 0.00 & 1.00 & 0.31 \\
\hline KLABIN $\left(x_{18}\right)$ & 0.57 & 0.09 & 0.22 & 0.42 & 0.88 & 0.50 & 0.47 & 0.33 & 0.50 & 0.50 & 0.00 & 0.86 & 0.77 \\
\hline BRASKEM $\left(x_{19}\right)$ & 0.65 & 0.55 & 0.89 & 0.63 & 0.94 & 0.83 & 0.73 & 0.67 & 0.67 & 1.00 & 0.67 & 0.57 & 1.00 \\
\hline ELEKEIROZ $\left(x_{20}\right)$ & 0.43 & 0.27 & 0.44 & 0.44 & 0.47 & 0.50 & 0.40 & 0.00 & 1.00 & 0.50 & 0.00 & 0.29 & 0.23 \\
\hline NATURA $\left(x_{21}\right)$ & 0.70 & 0.73 & 1.00 & 0.79 & 0.76 & 0.67 & 0.60 & 0.33 & 0.67 & 0.25 & 1.00 & 0.43 & 0.23 \\
\hline VITALYZE.ME $\left(x_{22}\right)$ & 0.13 & 0.00 & 0.11 & 0.04 & 0.00 & 0.00 & 0.00 & 0.00 & 0.00 & 0.00 & 0.00 & 0.00 & 0.00 \\
\hline $\operatorname{UNIPAR}\left(x_{23}\right)$ & 0.22 & 0.00 & 0.11 & 0.25 & 0.18 & 0.00 & 0.00 & 0.00 & 0.00 & 0.25 & 0.00 & 0.00 & 0.46 \\
\hline GERDAU $\left(x_{24}\right)$ & 0.57 & 0.00 & 0.44 & 0.48 & 0.47 & 0.17 & 0.00 & 0.33 & 0.17 & 0.25 & 0.00 & 0.43 & 0.77 \\
\hline
\end{tabular}

It should be noted that the market value was obtained by the product between the 'unit price of the stock' and the 'quantity of shares' of the organization dated December 31 of each year, which were collected through the Economática ${ }^{\circledR}$ database. Unlike the rankings cited above, because it did not present several groups of information, the construction of the rankings of the companies regarding the variable market value was organized by distributing the companies in a decreasing way in relation to this variable.

\subsubsection{Companies by Level of Social Disclosure}

Linear Programming Problems (LPP) were elaborated to determine the 2013 and 2014 rankings of companies with a high environmental impact according to the level of social disclosure. 
Table 6 - Information regarding the stocks of the companies that composed the sample.

(Source: Research data).

\begin{tabular}{l|l|c|c}
\hline \multicolumn{2}{c|}{ Market Value } & 2014 & 2015 \\
\hline \multirow{4}{*}{ Unit share price $(\mathrm{R} \$)$} & Minimum & 0.79 & 0.48 \\
\cline { 2 - 4 } & Maximum & 212.14 & 290.00 \\
\cline { 2 - 4 } & Mean & 27.21 & 25.29 \\
\cline { 2 - 4 } & Standard deviation & 47.33 & 58.41 \\
\hline \multirow{4}{*}{\begin{tabular}{l} 
Number of shares (UN) \\
\cline { 2 - 4 }
\end{tabular}} & Minimum & 4.560 & 4.559 \\
\cline { 2 - 4 } & Maximum & $13,044.497$ & $13,044.497$ \\
\cline { 2 - 4 } & Mean & $1,253.602$ & $1,209.223$ \\
\cline { 2 - 4 } $\begin{array}{l}\text { Market value }= \\
\text { unit share price } \times \\
\text { number of shares }(\mathrm{R} \$)\end{array}$ & Standard deviation & $2,841.363$ & $2,854.873$ \\
\cline { 2 - 4 } & Minimum & $64,087.00$ & $35,941.95$ \\
\cline { 2 - 4 } & Maximum & $125,096,726.23$ & $111,791,339.29$ \\
\cline { 2 - 4 } & Mean & $16,825,591.80$ & $13,964,524.64$ \\
\hline
\end{tabular}

Table 7 shows the rankings formed according to the level of social disclosure of the companies that composed the sample in the years of 2013 and 2014.

It can be seen from Table 7 that the company that presented in both years the highest social disclosure indexes, according to the Rover metric (2013) and the scalar games technique, was Natura. Besides Natura, Braskem $\left(4^{\text {th }}\right)$, Celul Irani $\left(7^{\text {th }}\right)$, Fibria $\left(8^{\text {th }}\right)$, Klabin $\left(12^{\text {th }}\right)$, Unipar $\left(16^{\text {th }}\right)$, Bradespar $\left(22^{\text {nd }}\right)$ and Panatlantica $\left(24^{\text {th }}\right)$ also did not change their ranking positions from the year 2013 to the ranking of the year 2014.

The other companies investigated varied their positions from 2013 to 2014, as is the case of the Qgep Part that changed its position as the $2^{\text {nd }}$ company with the highest social disclosure index in 2013 to the company with the $5^{\text {th }}$ highest social disclosure index in 2014 . However, it should be noted that among the five companies that occupied the top positions in the 2013 ranking, four remained among the five best positions of the following year and among the five companies with the worst positions in the 2013 ranking, four remained in positions in the year 2014 .

In light of the findings in Table 7, it should be noted that the organizations that generally ranked highest in the rankings were companies that showed an Annual Report or Sustainability Report. On the other hand, the organizations with the inferior positions of the rankings of 2013 and 2014 were those that did not disclose such reports during the investigated years.

\subsubsection{Companies by Level of Environmental Disclosure}

For the elaboration of the rankings of the organizations of the sample according to the level of environmental disclosure in the years of 2013 and 2014, Linear Programming Problems were also constructed. Table 8 shows the rankings obtained. 
Table 7 - Rankings of companies in relation to the level of social disclosure. STR = Strategy.

(Source: Research data).

\begin{tabular}{|c|c|c|c|c|c|c|c|c|}
\hline \multirow{2}{*}{ Trading Floor } & \multicolumn{4}{|c|}{ Result - 2013} & \multicolumn{4}{|c|}{ Result - 2014} \\
\hline & Position & Value & $\mathrm{Z}^{*}$ & STR & Position & Value & $\mathrm{Z}^{*}$ & STR \\
\hline NATURA & $1^{\mathrm{st}}$ & $x_{21}=0.47$ & 0.83 & Mixed & $1^{\mathrm{st}}$ & $x_{21}=0.52$ & 0.81 & Mixed \\
\hline QGEP PART & $2^{\text {nd }}$ & $x_{6}=0.31$ & 0.83 & Mixed & $5^{\text {th }}$ & $x_{6}=0.23$ & 0.59 & Mixed \\
\hline VALE & $3^{\text {rd }}$ & $x_{15}=0.22$ & 0.83 & Mixed & $2^{\text {nd }}$ & $x_{15}=0.37$ & 0.81 & Mixed \\
\hline BRASKEM & $4^{\text {th }}$ & $x_{19}=0.72$ & 0.65 & Mixed & $4^{\text {th }}$ & $x_{19}=0.77$ & 0.59 & Mixed \\
\hline COSAN & $5^{\text {th }}$ & $x_{3}=0.20$ & 0.65 & Mixed & $6^{\text {th }}$ & $x_{3}=1.00$ & 0.55 & Pura \\
\hline PETROBRAS & $6^{\text {th }}$ & $x_{5}=0.08$ & 0.65 & Mixed & $3^{\text {rd }}$ & $x_{5}=0.11$ & 0.81 & Mixed \\
\hline CELUL IRANI & $7^{\text {th }}$ & $x_{16}=0.51$ & 0.59 & Mixed & $7^{\text {th }}$ & $x_{16}=0.70$ & 0.52 & Mixed \\
\hline FIBRIA & $8^{\text {th }}$ & $x_{17}=0.49$ & 0.59 & Mixed & $8^{\text {th }}$ & $x_{17}=0.30$ & 0.52 & Mixed \\
\hline FER HERINGER & $9^{\text {th }}$ & $x_{8}=0.48$ & 0.39 & Mixed & $11^{\text {th }}$ & $x_{8}=1.00$ & 0.18 & Pure \\
\hline GERDAU & $10^{\text {th }}$ & $x_{24}=0.43$ & 0.39 & Mixed & $13^{\text {th }}$ & $x_{24}=0.80$ & 0.46 & Mixed \\
\hline ELEKEIROZ & $11^{\text {th }}$ & $x_{20}=0.09$ & 0.39 & Mixed & $9^{\text {th }}$ & $x_{20}=0.72$ & 0.35 & Mixed \\
\hline KLABIN & $12^{\text {th }}$ & $x_{18}=0.63$ & 0.32 & Mixed & $12^{\text {th }}$ & $x_{18}=1.00$ & 0.09 & Pure \\
\hline ULTRAPAR & $13^{\text {th }}$ & $x_{7}=0.30$ & 0.32 & Mixed & $14^{\text {th }}$ & $x_{7}=0.20$ & 0.46 & Mixed \\
\hline PARANAPANEMA & $14^{\text {th }}$ & $x_{1}=0.07$ & 0.32 & Mixed & $10^{\text {th }}$ & $x_{1}=0.28$ & 0.35 & Mixed \\
\hline RAIADROGASIL & $15^{\text {th }}$ & $x_{13}=0.62$ & 0.11 & Mixed & $18^{\text {th }}$ & $x_{13}=0.32$ & 0.10 & Mixed \\
\hline UNIPAR & $16^{\text {th }}$ & $x_{23}=0.38$ & 0.11 & Mixed & $16^{\text {th }}$ & $x_{23}=1.00$ & 0.11 & Pure \\
\hline PROFARMA & $17^{\text {th }}$ & $x_{12}=1.00$ & 0.10 & Pure & $15^{\text {th }}$ & $x_{12}=1.00$ & 0.11 & Pure \\
\hline BR PHARMA & $18^{\text {th }}$ & $x_{9}=1.00$ & 0.11 & Pure & $20^{\text {th }}$ & $x_{9}=0.59$ & 0.11 & Mixed \\
\hline VITALYZE.ME & $19^{\text {th }}$ & $x_{22}=0.66$ & 0.07 & Mixed & $17^{\text {th }}$ & $x_{22}=0.56$ & 0.10 & Mixed \\
\hline CREMER & $20^{\text {th }}$ & $x_{10}=0.34$ & 0.07 & Mixed & $19^{\text {th }}$ & $x_{10}=0.12$ & 0.10 & Mixed \\
\hline DIMED & $21^{\mathrm{st}}$ & $x_{11}=1.00$ & 0.04 & Pure & $23^{\text {rd }}$ & $x_{11}=0.29$ & 0.03 & Mixed \\
\hline BRADESPAR & $22^{\text {nd }}$ & $x_{14}=0.56$ & 0.02 & Mixed & $22^{\text {nd }}$ & $x_{14}=0.71$ & 0.03 & Mixed \\
\hline PETRORIO & $23^{\text {rd }}$ & $x_{4}=0.44$ & 0.02 & Mixed & $21^{\mathrm{st}}$ & $x_{4}=0.41$ & 0.11 & Mixed \\
\hline PANATLANTICA & $24^{\text {th }}$ & - & - & Pure & $24^{\text {th }}$ & - & - & Pure \\
\hline
\end{tabular}

Unlike Table 7, which refers to the rankings of social disclosure levels, in Table 8, which refers to the rankings of companies in light of the level of environmental disclosure, it is verified that the company that ranked $1^{\text {st }}$ in the ranking of 2013 did not remained in the same position in the ranking of 2014. The company Celulose Irani, which occupied the first position of the ranking in the year 2013, decreased its position in the following year, and started occupying the second position. On the other hand, Braskem, which occupied the 6th position in the year 2013, increased its position in 2014 , becoming the top of the ranking referring to the level of environmental disclosure. 
Table 8 - Rankings of companies in relation to the level of environmental disclosure. STR $=$ Strategy.

(Source: Research data).

\begin{tabular}{|c|c|c|c|c|c|c|c|c|}
\hline \multirow{2}{*}{ Trading Floor } & \multicolumn{4}{|c|}{ Result - 2013} & \multicolumn{4}{|c|}{ Result - 2014} \\
\hline & Position & Value & $\mathrm{Z}^{*}$ & STR & Position & Value & $\mathrm{Z}^{*}$ & STR \\
\hline CELUL IRANI & $1^{\mathrm{st}}$ & $x_{16}=0.60$ & 0.70 & Mixed & $2^{\text {nd }}$ & $x_{16}=0.16$ & 0.62 & Mixed \\
\hline COSAN & $2^{\text {nd }}$ & $x_{3}=0.27$ & 0.70 & Mixed & $9^{\text {th }}$ & $x_{3}=0.16$ & 0.44 & Mixed \\
\hline NATURA & $3^{\text {rd }}$ & $x_{21}=0.08$ & 0.70 & Mixed & $3^{\text {rd }}$ & $x_{21}=0.35$ & 0.47 & Mixed \\
\hline VALE & $4^{\text {th }}$ & $x_{15}=0.05$ & 0.70 & Mixed & $7^{\text {th }}$ & $x_{15}=0.45$ & 0.44 & Mixed \\
\hline ULTRAPAR & $5^{\text {th }}$ & $x_{7}=0.68$ & 0.22 & Mixed & 5 th & $x_{7}=0.24$ & 0.47 & Mixed \\
\hline BRASKEM & $6^{\text {th }}$ & $x_{19}=0.22$ & 0.22 & Mixed & $1^{\mathrm{st}}$ & $x_{19}=0.84$ & 0.62 & Mixed \\
\hline FIBRIA & $7^{\text {th }}$ & $x_{17}=0.09$ & 0.22 & Mixed & $11^{\text {th }}$ & $x_{17}=0.20$ & 0.31 & Mixed \\
\hline FER HERINGER & $8^{\text {th }}$ & $x_{8}=0.01$ & 0.22 & Mixed & $16^{\text {th }}$ & $x_{8}=0.48$ & 0.16 & Mixed \\
\hline PETROBRAS & $9^{\text {th }}$ & $x_{5}=0.72$ & 0.41 & Mixed & $6^{\text {th }}$ & $x_{5}=0.13$ & 0.47 & Mixed \\
\hline KLABIN & $10^{\text {th }}$ & $x_{18}=0.28$ & 0.41 & Mixed & $4^{\text {th }}$ & $x_{18}=0.28$ & 0.47 & Mixed \\
\hline GERDAU & $11^{\text {th }}$ & $x_{24}=0.62$ & 0.25 & Mixed & $8^{\text {th }}$ & $x_{24}=0.39$ & 0.44 & Mixed \\
\hline ELEKEIROZ & $12^{\text {th }}$ & $x_{20}=0.38$ & 0.25 & Mixed & $13^{\text {th }}$ & $x_{20}=0.54$ & 0.23 & Mixed \\
\hline PARANAPANEMA & $13^{\text {th }}$ & $x_{1}=0.82$ & 0.18 & Mixed & $14^{\text {th }}$ & $x_{1}=0.46$ & 0.23 & Mixed \\
\hline QGEP PART & $14^{\text {th }}$ & $x_{6}=0.18$ & 0.18 & Mixed & $10^{\text {th }}$ & $x_{6}=0.78$ & 0.31 & Mixed \\
\hline BRADESPAR & $15^{\text {th }}$ & $x_{14}=0.35$ & 0.04 & Mixed & $18^{\text {th }}$ & $x_{14}=0.46$ & 0.06 & Mixed \\
\hline RAIADROGASIL & $16^{\text {th }}$ & $x_{13}=0.30$ & 0.04 & Mixed & $21^{\mathrm{st}}$ & - & - & Mixed \\
\hline PETRORIO & $17^{\text {th }}$ & $x_{4}=0.23$ & 0.04 & Mixed & $15^{\text {th }}$ & $x_{4}=0.52$ & 0.16 & Mixed \\
\hline UNIPAR & $18^{\text {th }}$ & $x_{23}=0.13$ & 0.04 & Mixed & $12^{\text {th }}$ & $x_{23}=0.02$ & 0.31 & Mixed \\
\hline DIMED & $19^{\text {th }}$ & $x_{11}=0.54$ & 0.06 & Mixed & $17^{\text {th }}$ & $x_{11}=0.54$ & 0.06 & Mixed \\
\hline VITALYZE.ME & $20^{\text {th }}$ & $x_{22}=0.46$ & 0.06 & Mixed & $23^{\text {rd }}$ & - & - & Mixed \\
\hline PROFARMA & $21^{\mathrm{st}}$ & - & - & Mixed & $19^{\text {th }}$ & - & - & Mixed \\
\hline BR PHARMA & $22^{\text {nd }}$ & - & - & Mixed & $20^{\text {th }}$ & - & - & Mixed \\
\hline CREMER & $23^{\mathrm{rd}}$ & - & - & Mixed & $22^{\text {nd }}$ & - & - & Mixed \\
\hline PANATLANTICA & $24^{\text {th }}$ & - & - & Mixed & $24^{\text {th }}$ & - & - & Mixed \\
\hline
\end{tabular}

It should also be noted that, similarly to social disclosure rankings, in the rankings of environmental disclosure levels, there were companies that remained in the same position in both of the analyzed periods. Among these companies was Natura that remained in both years in $3^{\text {rd }}$ place, as well as Ultrapar, which occupied the $8^{\text {th }}$ position and Panatlantica which occupied the $24^{\text {th }}$ position. However, it can be seen that, unlike the social disclosure rankings, the changes compared to the first placements from the year 2013 to the year 2014 were higher. Among the companies with the least evidence of environmental issues, there is a similarity with social rankings, since among the five companies with the worst positions in 2013 , four remained in the five worst positions in 2014. 
It should again be noted that the companies that were in the top positions of the rankings are organizations that released Annual or Sustainability Reports of the analyzed years. And, unlike these companies, the organizations found in the lower ranks of the environmental rankings are those who did not disclose such reports.

\subsubsection{Companies by Level of Socio-environmental Disclosure}

For the construction of social and environmental rankings of 2013 and 2014 of the companies that composed the research sample, the Linear Programming Problems elaborated refer to vector games, that is, the model deals with social and environmental variables in the same LPP. The socio-environmental rankings of 2013 and 2014 are evidenced by means of Table 9.

Regarding the results presented in Table 9, it should be pointed out that Natura, which ranked $1^{\text {st }}$ in the ranking in 2013, fell, in the second year, to the $2^{\text {nd }}$ position. On the other hand, the company Braskem, which occupied the $4^{\text {th }}$ position in the year 2013, started to lead the ranking in the following year, being considered in 2014 the company with high environmental impact among those analyzed, with a higher level of socio-environmental disclosure.

It must also be emphasized that again there were companies that maintained their positions during the analyzed years. Among these are Ultrapar, occupying the $7^{\text {th }}$ position, Fibria, which occupied the $10^{\text {th }}$ position, Profarma, which occupied the 17 th position in the ranking and Panatlantica again, as has already been evidenced in the rankings of the level of social and environmental disclosure, was in the $24^{\text {th }}$ position. It can also be verified that, generally, the companies positioned in the first and last positions of the ranking of 2013, tended to remain in such positions in the following year.

As previously evidenced in the rankings regarding social disclosure and environmental disclosure, the companies belonging to the former are organizations that are concerned with disseminating Annual or Sustainability Reports. On the other hand, the companies with the worst ranking positions were those that did not show Annual or Sustainability Reports.

\subsubsection{Companies by Market Value}

Table 10 shows the results obtained by means of the variable market value for each one of the companies in the sample, together with their respective position in relation to such index.

In contrast to the companies that presented the highest market value indexes, as evidenced by Table 10, Petrobras, which is in the $1^{\text {st }}$ position in both years and Vale, which is in the $2^{\text {nd }}$, both in the ranking for the year 2014, and in the ranking for the year 2015 should be highlighted. In addition to these, other organizations Ultrapar $\left(4^{\text {th }}\right)$, Fibria $\left(5^{\text {th }}\right)$, Natura $\left(8^{\text {th }}\right)$, Cosan $\left(9^{\text {th }}\right)$, Fertilizantes Heringer $\left(22^{\text {nd }}\right)$ and Profarma $\left(19^{\text {th }}\right)$ remained in the same positions during both periods. 
Table 9 - Rankings of companies in relation to the socio-environmental disclosure level.

STR = Strategy. (Source: Research data).

\begin{tabular}{|c|c|c|c|c|c|c|c|c|}
\hline \multirow{2}{*}{ Trading Floor } & \multicolumn{4}{|c|}{ Result - 2013} & \multicolumn{4}{|c|}{ Result - 2014} \\
\hline & Position & Value & $\mathrm{Z}^{*}$ & STR & Position & Value & $\mathrm{Z}^{*}$ & STR \\
\hline NATURA & $1^{\mathrm{st}}$ & $x_{21}=0.33$ & 1.80 & Mixed & $2^{\text {nd }}$ & $x_{21}=0.22$ & 1.84 & Mixed \\
\hline VALE & $2^{\text {nd }}$ & $x_{15}=0.29$ & 1.80 & Mixed & $4^{\text {th }}$ & $x_{15}=0.14$ & 1.84 & Mixed \\
\hline CELUL IRANI & $3^{\text {rd }}$ & $x_{16}=0.17$ & 1.80 & Mixed & $5^{\text {th }}$ & $x_{16}=0.87$ & 1.08 & Mixed \\
\hline BRASKEM & $4^{\text {th }}$ & $x_{19}=0.12$ & 1.80 & Mixed & $1^{\text {st }}$ & $x_{19}=0.45$ & 1.84 & Mixed \\
\hline COSAN & $5^{\text {th }}$ & $x_{3}=0.08$ & 1.80 & Mixed & $9^{\text {th }}$ & $x_{3}=0.31$ & 1.21 & Mixed \\
\hline QGEP PART & $6^{\text {th }}$ & $x_{6}=1.00$ & 0.94 & Pure & $8^{\text {th }}$ & $x_{6}=0.38$ & 1.21 & Mixed \\
\hline ULTRAPAR & $7^{\text {th }}$ & $x_{7}=0.45$ & 0.69 & Mixed & $7^{\text {th }}$ & $x_{7}=0.02$ & 1.08 & Mixed \\
\hline FER HERINGER & $8^{\text {th }}$ & $x_{8}=0.39$ & 0.69 & Mixed & $15^{\text {th }}$ & $x_{8}=0.14$ & 0.76 & Mixed \\
\hline PETROBRAS & $9^{\text {th }}$ & $x_{5}=0.13$ & 0.69 & Mixed & $3^{\text {rd }}$ & $x_{5}=0.20$ & 1.84 & Mixed \\
\hline FIBRIA & $10^{\text {th }}$ & $x_{17}=0.02$ & 0.69 & Mixed & $10^{\text {th }}$ & $x_{17}=0.19$ & 1.21 & Mixed \\
\hline KLABIN & $11^{\text {th }}$ & $x_{18}=0.39$ & 0.78 & Mixed & $6^{\text {th }}$ & $x_{18}=0.11$ & 1.08 & Mixed \\
\hline GERDAU & $12^{\text {th }}$ & $x_{24}=0.31$ & 0.78 & Mixed & $11^{\text {th }}$ & $x_{24}=0.12$ & 1.21 & Mixed \\
\hline ELEKEIROZ & $13^{\text {th }}$ & $x_{20}=0.21$ & 0.78 & Mixed & $12^{\text {th }}$ & $x_{20}=0.40$ & 0.76 & Mixed \\
\hline PARANAPANEMA & $14^{\text {th }}$ & $x_{1}=0.09$ & 0.78 & Mixed & $13^{\text {th }}$ & $x_{1}=0.29$ & 0.76 & Mixed \\
\hline RAIADROGASIL & $15^{\text {th }}$ & $x_{13}=0.62$ & 0.14 & Mixed & $19^{\text {th }}$ & $x_{13}=0.22$ & 0.12 & Mixed \\
\hline UNIPAR & $16^{\text {th }}$ & $x_{23}=0.38$ & 0.14 & Mixed & $14^{\text {th }}$ & $x_{23}=0.16$ & 0.76 & Mixed \\
\hline PROFARMA & $17^{\text {th }}$ & $x_{12}=1.00$ & 0.12 & Pure & $17^{\text {th }}$ & $x_{12}=1.00$ & 0.14 & Pure \\
\hline BR PHARMA & $18^{\text {th }}$ & $x_{9}=1.00$ & 0.13 & Pure & $22^{\text {nd }}$ & - & - & Mixed \\
\hline BRA & $19^{\text {th }}$ & $x_{14}=0.32$ & 0.10 & Mixed & $21^{\mathrm{st}}$ & $x_{14}=0.17$ & 0.12 & Mixed \\
\hline PETRORIO & $20^{\text {th }}$ & $x_{4}=0.27$ & 0.10 & Mixed & $16^{\text {th }}$ & $x_{4}=1.00$ & 0.19 & Pure \\
\hline VITALYZE.ME & $21^{\mathrm{st}}$ & $x_{22}=0.27$ & 0.10 & Mixed & $18^{\text {th }}$ & $x_{22}=0.41$ & 0.12 & Mixed \\
\hline CREMER & $22^{\text {nd }}$ & $x_{10}=0.14$ & 0.10 & Mixed & $23^{\text {rd }}$ & - & - & Mixed \\
\hline DIMED & $23^{\text {rd }}$ & $x_{11}=1.00$ & 0.21 & re & $20^{\text {th }}$ & $x_{11}=0.20$ & 0.12 & Mixed \\
\hline PANATLANTICA & $24^{\text {th }}$ & - & - & Pure & $24^{\text {th }}$ & - & - & Mixed \\
\hline
\end{tabular}

It can also be seen from Table 10 that among the five companies that presented the best market value indexes in 2014, four remained in the top five positions in the year 2015. In relation to the five companies which were in the last positions in 2014, four of them also remained in the last positions in the following year. 
Table 10 - Rankings of companies in relation to market value. (*) In Brazilian Real Rates (R\$).

(Source: Research data).

\begin{tabular}{l|c|c|c|c}
\hline Trading floor & $\begin{array}{c}\text { Position } \\
(2013)\end{array}$ & $\begin{array}{c}\text { Market Value* } \\
(2013)\end{array}$ & $\begin{array}{c}\text { Position } \\
(2014)\end{array}$ & $\begin{array}{c}\text { Market Value* } \\
(2014)\end{array}$ \\
\hline PETROBRAS & $1^{\text {st }}$ & $125,096,726.23$ & $1^{\text {st }}$ & $111,791,339.30$ \\
\hline VALE & $2^{\text {nd }}$ & $107,134,332.37$ & $2^{\text {nd }}$ & $67,148,476.25$ \\
\hline BR PHARMA & $3^{\text {rd }}$ & $47,015,104.50$ & $24^{\text {th }}$ & $35,941.95$ \\
\hline ULTRAPAR & $4^{\text {th }}$ & $27,232,293.97$ & $4^{\text {th }}$ & $32,407,997.40$ \\
\hline FIBRIA & $5^{\text {th }}$ & $16,453,877.25$ & $5^{\text {th }}$ & $28,208,714.11$ \\
\hline KLABIN & $6^{\text {th }}$ & $14,635,202.58$ & $3^{\text {rd }}$ & $38,622,897.04$ \\
\hline GERDAU & $7^{\text {th }}$ & $13,182,534.29$ & $10^{\text {th }}$ & $5,869,625.52$ \\
\hline NATURA & $8^{\text {th }}$ & $12,752,406.87$ & $8^{\text {th }}$ & $10,000,601.71$ \\
\hline COSAN & $9^{\text {th }}$ & $10,807,194.45$ & $9^{\text {th }}$ & $9,726,141.32$ \\
\hline RAIADROGASIL & $10^{\text {th }}$ & $8,172,109.41$ & $7^{\text {th }}$ & $11,622,076.63$ \\
\hline BRASKEM & $11^{\text {th }}$ & $7,536,652.72$ & $6^{\text {th }}$ & $11,884,634.68$ \\
\hline UNIPAR & $12^{\text {th }}$ & $3,925,304.75$ & $17^{\text {h }}$ & $455,222.02$ \\
\hline BRADESPAR & $13^{\text {th }}$ & $3,708,486.79$ & $11^{\text {th }}$ & $1,545,270.96$ \\
\hline QGEP PART & $14^{\text {th }}$ & $1,756,646.65$ & $12^{\text {th }}$ & $1,452,029.07$ \\
\hline DIMED & $15^{\text {th }}$ & $967,370.40$ & $13^{\text {th }}$ & $1,322,110.00$ \\
\hline PARANAPANEMA & $16^{\text {th }}$ & $754,744.89$ & $15^{\text {th }}$ & $672,242.41$ \\
\hline PETRORIO & $17^{\text {th }}$ & $687,178.80$ & $14^{\text {th }}$ & $807,765.00$ \\
\hline CELUL IRANI & $18^{\text {th }}$ & $519,192.78$ & $16^{\text {th }}$ & $494,675.44$ \\
\hline PROFARMA & $19^{\text {th }}$ & $346,729.67$ & $19^{\text {th }}$ & $195,155.96$ \\
\hline CREMER & $20^{\text {th }}$ & $318,643.14$ & $18^{\text {th }}$ & $412,334.45$ \\
\hline PANATLANTICA & $21^{\text {st }}$ & $271,546.53$ & $20^{\text {th }}$ & $187,969.37$ \\
\hline FER HERINGER & $22^{\text {nd }}$ & $255,442.17$ & $22^{\text {nd }}$ & $72,706.95$ \\
\hline ELEKEIROZ & $23^{\text {rd }}$ & $220,395.00$ & $21^{\text {st }}$ & $173,482.35$ \\
\hline VITALYZE.ME & $24^{\text {th }}$ & $64,087.00$ & $23^{\text {rd }}$ & $39,181.56$ \\
\hline
\end{tabular}

\subsection{Degree of Correlation Between Rankings}

Table 11 shows the findings related to the degrees of association found through Kendall's correlation between the rankings of social disclosure levels and the market value rankings of the sample companies.

As shown in Table 11, there is a positive but weak and significant association between the social disclosure ranking of 2013 and the market value ranking of 2014. This result suggests that companies with higher levels of social disclosure were also those with the highest market values. Regarding the association between the social disclosure ranking of 2014 and the market value ranking of 2015, there is a positive, moderate and significant association, which implies that in this investigated period as well the organizations with the highest levels of social disclosure were also the ones with the highest market value. 
Table 11 - Correlation between rankings of social disclosures and those of market value. (Source: Research data).

\begin{tabular}{c|c|c}
\hline Period & Kendall Correlation & Values \\
\hline 2013 Social Disclosure - & Correlation coefficient & 0.290 \\
\cline { 2 - 3 } 2014 Market Value & Sig. & 0.047 \\
\hline 2014 Social Disclosure - & Correlation coefficient & 0.348 \\
\cline { 2 - 3 } 2015 Market Value & Sig. & 0.017 \\
\hline
\end{tabular}

These results converge with the findings of Qiu, Shaukat \& Tharyan (2014) in organizations belonging to the FTSE 350 index using regression and correlation and the findings of Verbeeten, Gamerschlag \& Moller (2016) which applied Pearson's correlation and panel data analysis by analyzing German companies. However, the findings of this research diverge from the results obtained by Santos, Araújo \& Leite Filho (2016), since these authors evidenced an inverse association between such variables in Brazilian civil construction companies by means of panel data. Moreover, these results also differ from the findings of Sousa, Silva, Ribeiro \& Weffort (2014), since when investigating Brazilian companies, by using Spearman correlation and panel data, the authors did not verify the association between such variables. Therefore, it is emphasized that such results may be specific of companies belonging to sectors with high environmental impact, and for this reason they need to pay special attention to the dissemination of social information.

In addition to such evidence, the difference observed in the strength of the degree of association between the rankings of the first and the second period should be noted. This finding leads to the assumption that there has been an increase in the importance attributed to the disclosure of social information by the market at the present time. Still, it is suggested through such findings that the qualification of voluntary disclosure by companies can positively reflect their market value, which stimulates the improvement of social disclosure in later periods.

In relation to the results found through the association between the environmental rankings and the market value rankings, verified through the Kendall correlation, they are exposed in Table 12.

Table 12 - Correlation between rankings of environmental disclosures and those of market value. (Source: Research data).

\begin{tabular}{c|c|c}
\hline Period & Kendall Correlation & Values \\
\hline 2013 Environmental Disclosure - & Correlation coefficient & 0.319 \\
\cline { 2 - 3 } 2014 Market Value & Sig. & 0.029 \\
\hline 2014 Environmental Disclosure - & Correlation coefficient & 0.471 \\
\cline { 2 - 3 } 2015 Market Value & Sig. & 0.001 \\
\hline
\end{tabular}

As shown in Table 12, in both periods investigated there was a positive, moderate and significant association between the rankings of the environmental disclosure level and the companies' market value rankings. These results indicate that companies with higher levels of environmental evidence tend to have the highest market values during the periods investigated. 
These results corroborate with the findings of Iatridis (2013) in companies from Malaysia, Olayinka \& Oluwamayowa (2014), in companies listed in Nigeria, Fazzini \& Dal Maso (2016), in Italian organizations and with the findings of Santos, Araújo \& Leite (2016), in 18 Brazilian construction companies which applied panel data analysis. In contrast, the results found do not corroborate with Sousa, Silva, Ribeiro \& Weffort's (2014) evidence in the Brazilian scenario, since the authors found an inverse association between such variables using Spearman correlation and panel data and it also diverges from the findings of Verbeeten, Gamerschlag \& Moller (2016) in 130 German companies which applied Pearson correlation and panel data.

However, it is emphasized that, as evidenced by the association between social disclosure and market value, Table 12 shows an increase in the degree of association of environmental disclosure with the market value of the first to the second period analyzed. Such evidence suggests that there was also an increase in the importance attributed by the market in the disclosure of environmental issues by companies with high environmental impact. Therefore, the qualification of the disclosure of this type of information can positively reflect the market value of the companies, which stimulates an improvement in relation to such disclosure in later periods by companies with high environmental impact.

Table 13 shows the results obtained through Kendall's correlation, in relation to the degrees of association between the rankings of social-environmental disclosure levels and the market value rankings of the analyzed organizations.

Table 13 - Correlation between rankings of social and environmental disclosures and those of market value. (Source: Research data).

\begin{tabular}{c|c|c}
\hline Year & Kendall Correlation & Values \\
\hline 2013 Socio-environmental - & Correlation coefficient & 0.341 \\
\cline { 2 - 3 } 2014 Market Value & Sig. & 0.020 \\
\hline 2013 Socio-environmental - & Correlation coefficient & 0.500 \\
\cline { 2 - 3 } 2014 Market Value & Sig. & 0.001 \\
\hline
\end{tabular}

It can be seen from Table 13 that in both analyzed periods there was a positive, moderate and significant association between the social-environmental disclosure rankings and the market value rankings. This result indicates that companies with higher levels of disclosure on issues related to their employees, society and the environment tend to present market values higher than their competitors who do not disclose such information.

These findings corroborate evidence from Qiu, Shaukat \& Tharyan (2014), FTSE 350 organizations, Klerk, Villiers \& Staden (2015), in 89 organizations from UK, Santana, Góis, Luca \& Vasconcelos (2015), in 114 Brazilian companies that publish Annual or Sustainability Reports in 2012, Bowerman \& Sharma (2016), also in companies from the United Kingdom and Japan and, Verbeeten, Gamerschlag \& Moller (2016) in 130 German companies. These studies used correlation and regression, panel data, multiple linear regression and Pearson correlation. However, the 
results obtained in this research do not corroborate with the findings of Rover \& Murcia (2010) and Murcia \& Santos (2012) in the Brazilian context using correlation and with the results of Morais (2014) in companies in Portugal, Spain and Italy.

Reinforcing the results related to the association of social disclosure and environmental disclosure with the market value of the companies, Table 13 shows an increase in the strength of the association from the first to the second period evaluated. This finding supports the idea that the market is becoming more interested and valuing organizations with high environmental impact that disclose information about their employees, society and the environment. Such finding encourages these organizations to highlight such issues in order to improve their perception in relation to thee investors, resulting in a market value superior to their competitors who do not worry about such disclosure.

In addition, such evidence encourages further research to evaluate the consistency of such relationships in later periods, since such studies would contribute to the analyzed organizations, assisting them in their dissemination practices on social and environmental issues.

\section{CONCLUSIONS}

After the use of the mathematical models, based on scalar and vector games, it can be concluded, in relation to the positioning of the companies of the sample according to the level of social disclosure, that the companies that were in the best positions were Natura, Qgep Part, Vale, and Braskem, and in the last positions were Panatlantica, Petrorio, Dimed and Bradespar. Regarding the accounting positioning of the sample companies, according to the level of environmental disclosure, Celul Irani, Vale and Ultrapar have the best positions. In contrast, the organizations with the lowest levels of environmental disclosure were Panatlantica, Cremer, Dimed, Br Pharma and Vitalyze.me.

Evaluating jointly the level of social and environmental disclosure of the organizations of high environmental impact belonging to the sample, it can be verified that among the companies with the best levels of social and environmental disclosure are Natura, Vale, Celul Irani and Fibria. In the lowest positions are Panatlantica, Dimed and Cremer. Regarding the rankings of the organizations according to the market value, Petrobras, Vale, Ultrapar and Fibria occupy the best positions, while Vitalyze.me, Elekeiroz, Fer Heringer and Panatlantica are in the lowest rankings.

Regarding the association of social, environmental and socio-environmental disclosure with the market value of Brazilian companies with high environmental impact, the results of this research converge with the conclusion of Dye (1985) regarding Voluntary Disclosure Theory. This fact results from the empirical evidence that companies with higher levels of social, environmental and socio-environmental voluntary disclosures tend to present market values superior to their competitors that disclose less information of these genres.

Finally, the results of the present study corroborate the research that affirms that greater voluntary disclosure increases the competitive advantage of the company, since companies with greater 
transparency in relation to social and environmental issues presented better market values. Thus, a perception by Eccles, Herz, Keegan \& Phillips (2001), Konar \& Cohen (2001), Kothari, Li \& Short (2009), Moreira, Gomes, Dias Filho \& Conceição (2014) and Nekhili, Hussainey, Cheffi \& Tchakoute-Tchuigoua (2016) that the disclosure of voluntary information tends to bring benefits to the organizations is confirmed in this study.

Therefore, through this research, the relevance of companies belonging to the sectors of high environmental impact is disclosed, which will involve information about their employees, the community in general, the environment in which they are inserted, the use of natural resources and the way through which they protect the environment. Therefore, it is recommended for organizations with high environmental impact that they seek to improve their market values; that they disclose Rover's (2013) subcategories, since the greater disclosure of these is associated with a higher market value of such companies.

\section{REFERENCES}

[1] Amorim E de A, Romero R \& Mantovani JRS. 2009. Fluxo de potência ótimo descentralizado utilizando algoritmos evolutivos multiobjetivo. Sba: Controle \& Automação Sociedade Brasileira de Automatica, 20(2): 217-232.

[2] Antunes CH \& Alves MJ. 2012. Programação linear multiobjetivo-métodos interativos e software. In: Congreso Latino-Iberoamericano de Investigación Operativa, 16, 2012, Rio de Janeiro. Anais... Congreso Latino-Iberoamericano de Investigación Operativa.

[3] Azuma RM. 2011. Otimização multiobjetivo em problema de estoque e roteamento gerenciados pelo fornecedor. 99 f. 2011. Dissertação (Mestrado em Engenharia Elétrica) - Faculdade de Engenharia Elétrica e de Computação, Universidade Estadual de Campinas, Campinas.

[4] BAUER M \& NAIME R. 2012. Estado da arte da evidenciação social e ambiental voluntária. REUNIR: Revista de Administração, Contabilidade e Sustentabilidade, 2(2): 39-60.

[5] Bowerman S \& Sharma UP. 2016. The effect of corporate social responsibility disclosures on share prices in Japan and the UK. Corporate Ownership and Control, 13(2): 202-216.

[6] Brandt F, Fischer F, Harrenstein P \& Shoham Y. 2009. Ranking games. Artificial Intellingence, 173: 221-239.

[7] Bushman RM \& SMith AJ. 2001. Financial accounting information and corporate governance. Journal of accounting and Economics, 32(1): 237-333.

[8] Carmelossi M DE S. 2014. Funções de aglutinação baseadas em eficiência: uma abordagem DEA para problemas de otimização multiobjetivo. Programa de Pós-Graduação em Engenharia de Produção, Universidade Federal de Itajubá, Itajubá, MG, Brasil.

[9] Chaves EPS \& Pimenta Júnior T. 2013. Relação entre valor de mercado e ativo intangível na bovespa. Revista de Administração IMED, 3(3): 239-251.

[10] CINTRA YC. 2011. A integração da sustentabilidade às práticas de controle gerencial das empresas no Brasil. Faculdade de Economia, Administração e Contabilidade, Universidade de São Paulo, São Paulo, SP, Brasil. 
[11] Cormier D, Magnan M \& Van Velthoven B. 2005. Environmental disclosure quality in large German companies: economic incentives, public pressures or institutional conditions? European Accounting Review, 14(1): 3-39.

[12] Dimand MA \& Dimand RW. 1996. The history of game theory, Volume I: from the beginnings to 1945. London: Routledge.

[13] DyE RA. 1985. Disclosure of nonproprietary information. Journal of Accounting Research, 23(1): $123-145$.

[14] DYE RA. 2001. An evaluation of "essays on disclosure" and the disclosure literature in accounting. Journal of Accounting and Economics, 32(1): 181-235.

[15] Eccles RG, Herz RH, Keegan EM \& Phillips DM. 2001. The Value Reporting revolution: moving beyond the earnings game. Price water house Coopers. New York: John Wiley \& Sons, Inc.

[16] FAzZini M \& DAL MAso L. 2016. The value relevance of 'assured' environmental disclosure. The Italian experience. Sustainability Accounting, Management and Policy Journal, 7(2): 225-245.

[17] Fernández FR \& PUeRTo J. 1996. Vector linear programming in zero-sum multicriteria matrix games. Journal of Optimization Theory and Applications, 89: 115-127.

[18] FIANI R. 2004. Teoria dos jogos: para cursos de Administração e economia. Rio de Janeiro: Elsevier.

[19] Francis J, NANDa D \& Olsson P. 2008. Voluntary disclosure, earnings quality, and cost of capital. Journal of Accounting Research, 46(1): 53-99.

[20] Healy PM \& PALEPU KG. 2001. Information asymmetry, corporate disclosure, and the capital markets: A review of the empirical disclosure literature. Journal of Accounting and Economics, 31(1): 405-440.

[21] IATRIDIS GE. 2013. Environmental disclosure quality: Evidence on environmental performance, corporate governance and value relevance. Emerging Markets Review, 14: 55-75.

[22] KAVESKI IDS. 2013. Grau de relacionamento entre os indicadores de mercado de capitais, os indicadores econômico-financeiro e o retorno da ação, nas empresas brasileiras. Programa de PósGraduação em Ciências Contábeis da Universidade Regional de Blumenau, Blumenau, SC, Brasil.

[23] Klerk M, Villiers C \& Staden CV. 2015. The influence of corporate social responsibility disclosure on share prices: evidence from the United Kingdom. Pacific Accounting Review, 27(2): 208-228.

[24] Konar S \& Cohen MA. 2001. Does the market value environmental performance? Review of Economics and Statistics, 83(2): 281-289.

[25] Kothari SP, Li X \& Short JE. 2009. The effect of disclosures by management, analysts, and business press on cost of capital, return volatility, and analyst forecasts: A study using content analysis. The Accounting Review, 84(5): 1639-1670.

[26] Kreuzberg F. 2013. Indicadores econômicos versus indicadores sociais: uma análise de empresas listadas na BM\&FBovespa por meio da teoria dos jogos. Programa de Pós-Graduação em Ciências Contábeis da Universidade Regional de Blumenau, Blumenau, SC, Brasil.

[27] Kroenke A. 2014. Jogos vetoriais no posicionamento contábil das empresas de metalurgia e siderurgia listadas na BM\&FBovespa. Programa de Pós-Graduação em Métodos Numéricos em Engenharia. Universidade Federal do Paraná, Curitiba, PR, Brasil. 
[28] Kroenke A, Hein N \& Wilhelm VE. 2015. Jogos vetoriais como ferramenta de avaliação econômico-financeira: um estudo multicritério. In: SBPO - Simpósio Brasileiro de Pesquisa Operacional, 2015, Porto de Galinhas. Anais... SBPO.

[29] LANZANA AP. 2004. Relação entre disclosure e governança corporativa das empresas brasileiras. 165f. Dissertação (Mestrado em Administração) - Faculdade de Economia, Administração e Contabilidade, Universidade de São Paulo, São Paulo.

[30] LEONETI AB. 2016. Considerations regarding the choice of ranking multiple criteria decision making methods. Pesquisa. Operacional, 36(2): 259-277.

[31] LuCE D \& Raiffa H. 1957. Games and decisions. New York: John Wiley and Sons.

[32] Magro CBD, Gorla MC, Kroenke A \& Hein N. 2015. Ranking das cooperativas agropecuárias: um estudo dos indicadores de desempenho e a relação com atributos de governança corporativa. Organizações Rurais \& Agroindustriais, 17(2): 253-268.

[33] Malacrida MJC \& YAmamoto MM. 2006. Governança corporativa: nível de evidenciação das informações e sua relação com a volatilidade das ações do Ibovespa. Revista Contabilidade $e$ Finanças, 17: 65-79.

[34] Mármol A \& Monroy L. 1999. Aplicaciones económicas. In: Bilbao JM \& Fernández FR (Orgs.), Avances em teoria de juegos com aplicaciones económicas y sociales. Sevilla: Secretariado de publicaciones de la Universidad de Sevilla, 71-104.

[35] Martins G DE A \& TheóPhilo CR. 2007. Metodologia da investigação científica para ciências sociais. São Paulo: Atlas.

[36] Monroy L \& Mármol AM. 1999. Estrategias de seguridad Pareto Óptimas en modelos de interacción entre empresas. Cuadernos de Ciencias Económicas y Empresariales, 36: 7-16.

[37] Monroy L, Mármol AM \& Rubiales V. 2008. A bargaining model for finite $n$-person multicriteria games. International Game Theory Review, 11: 1-19.

[38] MoraIS MRPB DE. 2014. Corporate social responsibility levels and firm performance: Evidence from countries in crisis. Faculdade de Economia, Universidade Nova de Lisboa, Lisboa, Portugal.

[39] Moreira NB, Gomes SM da S, Dias Filho JM \& Conceição MG. 2014. Fatores que Impactam a Divulgação Voluntária de Informações Socioambientais na Percepção dos Gestores. REUNIR: Revista de Administração, Contabilidade e Sustentabilidade, 4(1): 62-82.

[40] Murcia FD. 2009. Fatores Determinantes do Nível de Disclosure Voluntário de Companhias Abertas no Brasil. Faculdade de Economia, Administração e Contabilidade, Universidade de São Paulo, São Paulo, SP, Brasil.

[41] MURCIA FD \& SANTOS A DOS. 2012. Discretionary-based disclosure: evidence from the Brazilian market. BAR - Brazilian Administration Review, 9(1): 88-109.

[42] NEIVA RA. 1999. Valor de mercado da empresa: modelos de avaliaçãoeconômico-financeira de empresas, exemplos de avaliação com cálculos de valores, subsídios para privatização, compra e venda, cisão, fusão e incorporação. 3 ed. São Paulo: Atlas.

[43] Nekhili M, Hussainey K, Cheffi W \& Tchakoute-Tchuigoua H. 2016. R\&D narrative disclosure, corporate governance and market value: Evidence from France. Journal of Applied Business Research, 32(1): 1-38. 
[44] Olayinka AO \& Oluwamayowa IO. 2014. Corporate environmental disclosures and market value of quoted companies in Nigeria. The Business \& Management Review, 5(3): 171-184.

[45] Ostolaza MCN. 1969. Problema de Adopcion de Decisiones Frente a la Incentidumbre en la Agricultura. Revista de Estudios Agrosociales, 68: 7-21.

[46] PLM. 2009. Programação Linear e Mista v. 3.0. Blumenau: Copyright.

[47] Puerto J, Hinojosa MA, Mármol AM, Monroy L \& Fernández FR. 1999. Solution concepts for multiple objective $n$-person games. Investigaçao Operacional, 19: 193-209.

[48] QIU Y, Shaukat A \& Tharyan R. 2014. Environmental and social disclosures: Link with corporate financial performance. The British Accounting Review, 30: 1-15.

[49] RAO SS. 1996. Engineering optimization: theory and practice. 3 ed. USA: John Wiley \& Sons.

[50] Rover S. 2013. Disclosure socioambiental e custo de capital próprio de companhias abertas no Brasil. Faculdade de Economia, Administração e Contabilidade, Universidade de São Paulo, São Paulo, SP, Brasil.

[51] Rover S \& Murcia FD. 2010. Influência do Disclosure Voluntário Econômico e Socioambiental no Custo de Capital Próprio das Empresas Brasileiras. In: CONGRESSO ANPCONT, 4., 2010, Natal. Anais... ANPCONT.

[52] Rover S \& Santos A. 2014. Revisitando os Determinantes do Disclosure Voluntário Socioambiental no Brasil: Em Busca de Robustez na Mensuração da Variável Socioambiental. Contabilometria, 1(2): 15-35.

[53] Rubiales V, Monroy L \& Mármol AM. 2017. Diseño de un ranking relativo con indicadores multicriterio. Una aplicación al sector bancario español. XI Reunión del Grupo Español de Decisión Multicriterio. Málaga, España.

[54] Salotti BM \& Yамамото MM. 2005. Ensaio sobre a teoria da divulgação. BBR - Brazilian Business Review, 2(1): 53-70.

[55] Santana LM de, Góis AD, LuCa MMM de \& Vasconcelos AC DE. 2015. Relação entre disclosure socioambiental, práticas de governança corporativa e desempenho empresarial. Revista Organizações em Contexto, 11(21): 49-72.

[56] Santos LM da S, Araújo RA de M \& Leite Filho PAM. 2016. Divulgação Voluntária e o Valor de Mercado: Um Estudo nas Empresas Brasileiras de Construção Civil Listadas na BM\&FBovespa. In: CONGRESSO ANPCONT, 10, 2016, Ribeirão Preto. Anais... ANPCONT.

[57] Sobhani FA, Amran A \& Zainuddin Y. 2009. Revisiting the practices of corporate social and environmental disclosure in Bangladesh. Corporate Social Responsibility and Environmental Management, 16(3): 167-183.

[58] SouZA CB. 2013. Valor de mercado e disclosure voluntário: estudo empírico em companhias listadas na BM\&FBOVESPA. 101 f. Dissertação (Mestrado em Ciências Contábeis) - Fundação Escola de Comércio Álvares Penteado - FECAP, São Paulo.

[59] Sousa CB de, Silva AF da, Ribeiro M de S \& WefFort EFJ. 2014. Valor de mercado e disclosure voluntário: estudo empírico em companhias listadas na BM\&FBOVESPA. Revista Ambiente Contábil, 6(2): 94-115.

[60] IBM SPSS. 2013. IBM SPSS statistics 22. New York: IBM Corp. 
[61] UYAR A \& KILIÇ M. 2012. Value relevance of voluntary disclosure: evidence from Turkish firms. Journal of Intellectual Capital, 13(3): 363-376.

[62] Verbeeten FHM, Gamerschlag R \& Möller K. 2016. Are CSR disclosures relevant for investors? Empirical evidence from Germany. Management Decision, 54(6): 1359-1382.

[63] VerRecchia RE. 1983. Discretionary disclosure. Journal of Accounting and Economics, 5: 179-194.

[64] Yамамото MM \& SALOtті BM. 2006. Informação contábil: estudos sobre a sua divulgação no mercado de capitais. São Paulo: Atlas.

[65] Zeleny M. 1976. Linear Multiobjetive Programming. Berlin: Springer Verlag.

[66] ZelenY, M. 1982. Multiple criteria decision making. New Yor: McGraw-Hill. 